University of Pennsylvania Carey Law School

Penn Law: Legal Scholarship Repository

Faculty Scholarship at Penn Law

3-1-2004

\title{
Is the Federal Circuit Succeeding? An Empirical Assessment of Judicial Performance
}

Polk Wagner

University of Pennsylvania Carey Law School

Lee Petherbridge

Independent

Follow this and additional works at: https://scholarship.law.upenn.edu/faculty_scholarship

Part of the Courts Commons, and the Intellectual Property Law Commons

\section{Repository Citation}

Wagner, Polk and Petherbridge, Lee, "Is the Federal Circuit Succeeding? An Empirical Assessment of Judicial Performance" (2004). Faculty Scholarship at Penn Law. 7.

https://scholarship.law.upenn.edu/faculty_scholarship/7

This Article is brought to you for free and open access by Penn Law: Legal Scholarship Repository. It has been accepted for inclusion in Faculty Scholarship at Penn Law by an authorized administrator of Penn Law: Legal Scholarship Repository. For more information, please contact PennlawIR@law.upenn.edu. 
University of Pennsylvania Law School

ILE

INSTITUTE FOR LAW AND ECONOMICS

A Joint Research Center of the Law School, the Wharton School, and the Department of Economics in the School of Arts and Sciences at the University of Pennsylvania

\title{
RESEARCH PAPER No. 04-08 \\ IS THE FEDERAL COURT SUCCEEDING? \\ AN EMPIRICAL ASSESSMENT OF \\ Judicial Performance
}

\author{
R. Polk Wagner \\ University of Pennsylvania Law School
}

March 2004

This paper can be downloaded without charge from the Social Science Research Network Electronic Paper Collection:

http://ssrn.com/abstract=511003 


\title{
IS THE FEDERAL CIRCUIT SUCCEEDING? AN EMPIRICAL ASSESSMENT OF JUDICIAL PERFORMANCE
}

\author{
R. POLK WAGNER ${ }^{\dagger}$ \\ LEE PETHERBRIDGE ${ }^{\dagger \dagger}$
}

As an appellate body jurisdictionally demarcated by subject matter rather than geography, the United States Court of Appeals for the Federal Circuit occupies a unique role in the federal judiciary. This controversial institutional design has profoundly affected the jurisprudential development of legal regimes within its purview-especially in patent law, which the Federal Circuit has come to thoroughly dominate in its two decades of existence.

In this Article, we assess the court's performance against its basic premise: that, compared to prior regional circuit involvement, centralization of legal authority in the Federal Circuit will yield a clearer, more coherent, and more predictable legal infrastructure for patent law. Using empirical data obtained from a novel study of the Federal Circuit's jurisprudence of claim construction-the interpretation of language defining a patent's scope-we conclude that, on this indicator at least, the result has been decidedly mixed, although there are some encouraging signs.

Specifically, the study indicates that the Federal Circuit is sharply divided between two basic methodological approaches to claim construction, each of which leads to distinct results. The dominant analytic framework gained additional favor during the period of the study, and yet the court became increasingly polarized. We also find that the significantly different approaches to claim construction followed by individual Federal Circuit judges has led to panel dependency; claim construction analysis is clearly affected by the composition of the three-judge panel that hears and decides the case.

While little in the results of this study would lead one to conclude that the court has been an unqualified success, we believe that the picture of the Federal Circuit that emerges is of a court in broad transition. Driven in part by new appointments and an effort to respond to its special mandate, a new Federal Circuit is emerging -one that appears to be more rules-driven and more consistent than be-

${ }^{\dagger}$ Assistant Professor, University of Pennsylvania Law School. Web site: http:// polk.pennlaw.net. Comments appreciated: polk@law.upenn.edu.

${ }^{+\dagger}$ J.D., University of Pennsylvania Law School, 2002.

Thanks to Jason Johnston, Mark Lemley, Kristin Madison, Craig Nard, Nate Persily, Richard Posner, Arti Rai, Kim Lane Scheppele, Reed Shuldiner, Phil Weiser, and participants at workshops at the University of Pennsylvania Law School, the George Washington University Law School, and the 2003 American Law and Economics Association for helpful comments on earlier drafts. Thanks also to Christian Chu for his data; to Kristin Madison, Dan Kessler, and Reed Shuldiner for statistical advice; and to Patrick Mirville, Bill Mulherin, and Ron Day for research assistance. All errors are our own. For more information and related research, see http://www.fedcir.org. 
fore. It is too early to be sure, but the findings here, perhaps bolstered by the procedural and jurisprudential reform suggestions we derived from the results, suggest that the Federal Circuit's unique position in the judiciary may yet be vindicated.

INTRODUCTION. 1107

I. Designing the Federal Circuit: A Doctrinal AND

THEORETICAL BACKGROUND

A. The Theory of the Federal Circuit

B. The Special Mandate of Claim Construction ..............................1117

1. A (Brief) Primer on Claim Construction ............................. 1117

2. Markman and the Express Mandate...................................... 1120

C. A Look Inside: Claim Construction and the Federal Circuit ...........1124

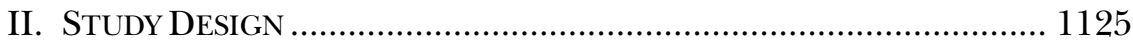

A. Measuring Jurisprudence: Court Opinions as Data....................1125

B. Procedural Versus Holistic: Selecting Measurement Criteria ............1130

1. A Review of the Literature..................................................... 1131

2. "Bottom Up" Measurement Design ...................................... 1133

C. Developing the Coding Instrument ......................................1136

D. Evaluating the Measurement_Criteria I: Reliability....................1139

E. Evaluating the Measurement_Criteria II: Validity.....................1140

1. Methodology as a Driver of Claim Construction ................. 1141

2. The Reality of the Procedural/Holistic Dichotomy.............. 1142

3. Testing the Procedural/Holistic Categories ......................... 1143

F. Data Collection and Measurement............................................1145

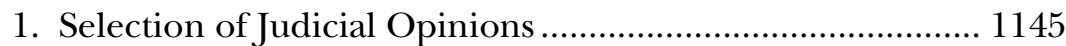

2. Coding Judicial Opinions ................................................... 1147

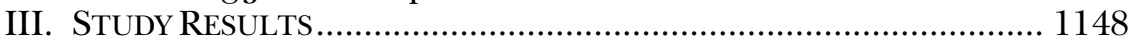

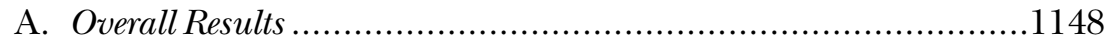

B. Methodological Trends over Time ...........................................1149

1. Overall Trends..................................................................... 1150

2. Authorship Activity Patterns .............................................. 1152

C. The Methodology of Federal Circuit Judges................................1156

1. Descriptive Data...................................................................... 1156

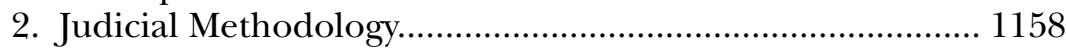

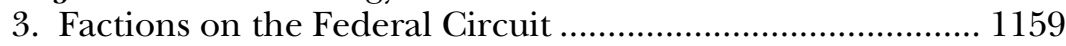

4. Judicial (In) consistency.......................................................... 1161

D. Predicting the Federal Circuit: Panel and Author Dependency

in Claim Construction ................................................................1163

1. Panel Membership and Methodology ................................. 1163

2. Dependency and Factions .................................................... 1166

3. Dependency, Factions, and Panels ..................................... 1168

4. The Institutional Implications of Panel Dependency.......... 1169 
IV. SuCCESS AND THE FEDERAL CiRCUIT: The IMPLICATIONS AND SOME POLICY PRESCRIPTIONS.

A. Is the Federal Circuit Succeeding?..............................................1171

B. Policy Recommendations.

1. The Importance of Panel Composition Information ........... 1174

2. Standardize (the Procedural) Methodological Approach .. 1176

3. Taking Methodology Seriously.

4. Evangelism and Enforcement: The Role of

Individual Judges

5. Seeking External Assistance: The Role of the

Supreme Court

\section{INTRODUCTION}

In the last two decades, ${ }^{1}$ the United States Court of Appeals for the Federal Circuit has become, by far, the most powerful and influential force in the U.S. patent system. ${ }^{2}$ The significance of this development is impossible to overstate: even as the patent system has grown in economic importance, ${ }^{3}$ technological complexity, ${ }^{4}$ and public awareness, the administration of the entire enterprise increasingly depends upon the twelve active judges of the Federal Circuit. ${ }^{5}$

${ }^{1}$ The Federal Circuit was created by the Federal Courts Improvement Act of 1982, Pub. L. No. 97-164, 96 Stat. 25 (codified as amended in scattered sections of 28 U.S.C.).

${ }^{2}$ This fact is widely acknowledged. See, e.g., Mark D. Janis, Patent Law in the Age of the Invisible Supreme Court, 2001 U. ILL. L. REV. 387, 387 ("The Court of Appeals for the Federal Circuit ... has become the de facto supreme court of patents.").

${ }^{3}$ See generally Fred Warshofsky, The PAtent Wars: The Battle to OWn the WORLD'S TECHNOLOGY (1994) (noting the critical nature of patents in economic development).

${ }^{4}$ See, e.g., John R. Allison \& Mark A. Lemley, The Growing Complexity of the United States Patent System, 82 B.U. L. REv. 77, 79 (2002) ("By almost any measure . . the patents issued in the late 1990s are more complex than those issued in the 1970s.").

${ }^{5}$ See 28 U.S.C. $\$ 44($ a) (2000) (authorizing up to twelve judges). As of January 2004 , all seats are filled. Of the current judges, two have advanced degrees in scientific fields (Judges Newman and Lourie both hold Ph.D.s in Chemistry), four have professional patent-related experience (Judges Newman, Lourie, Gajarsa, and Linn), three have policy-legislative experience (Judges Michel, Rader, and Prost), and two have advanced degrees in economics or business (Judges Gajarsa and Prost). See U.S. Court of Appeals for the Federal Circuit, Judicial Biographies, at http://www.fedcir.gov/ judgbios.html (last modified Jan. 22, 2004). 
Conferring such dominating power on the Federal Circuit has long been justified by the premise that this centralization of legal authority will yield a clearer, more coherent, more predictable legal infrastructure for the patent system. Indeed, as a response to widespread dissatisfaction due to confusion and uncertainty under the decentralized administration of the patent law, the Federal Circuit was created to play this very role. ${ }^{6}$ And since its inception, the court-with some assistance from the Supreme Court ${ }^{7}$-has moved aggressively in support of its widely perceived mandate. ${ }^{8}$

This mandate gives rise to the obvious (yet surprisingly ephemeral) question concerning the Federal Circuit's role in the patent system: is it succeeding? Has the mandate been fulfilled? Has this grand experiment in allocating judicial authority resulted in clearer, more consistent, more coherent rules surrounding patents? ${ }^{9}$ This is a

${ }^{6}$ See S. REP. No. 97-275, at 14-16 (1981), reprinted in 1982 U.S.C.C.A.N. 11, 14-15 (stating that the creation of a centralized court to hear suits related to patents will provide doctrinal stability in the field of patent law, which will decrease unnecessary uncertainties in the patent system and thereby increase innovation); COMM'N ON Revision of the Fed. Court Appellate Sys., Structure and Internal Procedures: RECOMMENDATIONS FOR CHANGE (1975), reprinted in 67 F.R.D. 195, 220 (1975) ("The additional appellate capacity for nationally binding decisions which a national court of appeals would provide can be expected to fulfill [the monitoring] function [over the complex area of patent law and policy]."). Perhaps the seminal work considering the formation of the Federal Circuit and its theoretical basis is Rochelle Cooper Dreyfuss, The Federal Circuit: A Case Study in Specialized Courts, 64 N.Y.U. L. REV. 1 (1989).

${ }^{7}$ Note in particular the Supreme Court's decision in Markman v. Westview Instruments, Inc. (Markman II), 517 U.S. 370, 388-90 (1996), allocating the authority to interpret patent claims to judges. The importance of Markman II is explored at length below. Infra Part I.

${ }^{8}$ The decisions in Markman $v$. Westview Instruments, Inc. (Markman I), 52 F.3d 967 (Fed. Cir. 1995), and Cybor Corp. v. FAS Technologies, Inc., 138 F.3d 1448 (Fed. Cir. 1998), are especially relevant in this context, as we discuss below. Infra Part I.

We note, however, that the Supreme Court's opinion in Holmes Group, Inc. v. Vornado Air Circulation Systems, Inc., 535 U.S. 826, 834 (2002), holding that permissive counterclaims arising under the patent law do not trigger Federal Circuit appellate jurisdiction, may represent a shift in that Court's thinking by at least raising the possibility of patent decisions being made by bodies other than the Federal Circuit.

${ }^{9}$ We analyze the implementation of these goals (i.e., those expressed in the legislative proceedings surrounding the creation of the Federal Circuit) on their own terms, rather than analyze whether they are ultimately socially beneficial. Several commentators have argued that uncertainty with respect to at least some aspects of the patent system might be useful. See, e.g., Ian Ayres \& Paul Klemperer, Limiting Patentees' Market Power Without Reducing Innovation Incentives: The Perverse Benefits of Uncertainty and Non-Injunctive Remedies, 97 MiCH. L. REV. 985, 986 (1999) ("The combination of [uncertainty and delay in patent litigation] might induce a limited amount of infringement that enhances social welfare ...."); Howard F. Chang, Patent Scope, Antitrust Policy, and Cumulative Innovation, 26 RAND J. ECON. 34, 50-51 (1995) (arguing that 
question to which scholars, ${ }^{10}$ the bar, ${ }^{11}$ and even judges ${ }^{12}$ are now turning with increasing interest-a reconsideration of the institutional

courts could achieve optimal incentive for successive innovations by implementing a randomized policy that delivered to patentees, on average, the correct payoff for an innovation's actual social value in light of subsequent innovations); Jerry R. Green \& Suzanne Scotchmer, On the Division of Profit in Sequential Innovation, 26 RAND J. ECON. 20, 21-22 (1995) (arguing that patent scope should be varied for successive innovations to ensure that each innovator is appropriately incentivized); Suzanne Scotchmer, Standing on the Shoulders of Giants: Cumulative Research and the Patent Law, 5 J. ECON. PERSP. 29, 35-36 (1991) (noting that uncertainty in the scope of patent protection may create incentives encouraging the development of new products); see also infra Part III.D. 4 and note 180 (discussing the uncertainty that results from panel dependency). Analyzing whether the goals of the Federal Circuit are themselves worthy is a question beyond the scope of this Article. However, for a discussion of some underlying difficulties surrounding the goals of the Federal Circuit, see Arti K. Rai, Engaging Facts and Policy: A Multi-Institutional Approach to Patent System Reform, 103 COLUM. L. REv. 1035, 1037-38 (2003).

${ }^{10}$ See, e.g., Christian A. Chu, Empirical Analysis of the Federal Circuit's Claim Construction Trends, 16 BERKELEY TECH. L.J. 1075, 1078-79 (2001) (suggesting the Federal Circuit has failed to achieve greater predictability); John F. Duffy, On Improving the Legal Process of Claim Interpretation: Administrative Alternatives, 2 WASH. U. J.L. \& POL'Y 109 (2000) (considering future innovations in claim interpretation that might solve procedural inefficiencies inherent in the current system of consolidated Federal Circuit review of patent appeals); Mark A. Lemley, Rational Ignorance at the Patent Office, $95 \mathrm{Nw}$. U. L. REV. 1495, 1496 (2001) (asserting that a more intensive patent evaluation process is unwarranted); Craig Allen Nard, Process Considerations in the Age of Markman and Mantras, 2001 U. ILL. L. REV. 355, 357 (2001) [hereinafter Nard, Process Considerations] (calling for the Federal Circuit to accept interlocutory appeals of district court claim interpretations in order to promote certainty); Craig Allen Nard, A Theory of Claim Interpretation, 14 HARV. J.L. \& TECH. 1, 82 (2000) [hereinafter Nard, Claim Interpretation] (contending that the Federal Circuit uses a theory of claim construction called "hypertextualism" and concluding that it is responsible for the court's failure to achieve certainty and coherence in its jurisprudence); Rai, supra note 9, at 1040 (arguing that the Federal Circuit has arrogated power over fact finding to the detriment of the patent system); Arti Kaur Rai, Regulating Scientific Research: Intellectual Property Rights and the Norms of Science, 94 Nw. U. L. REV. 77, 79 (1999) (asserting that legal change has been out of step with the "instrumental goals of intellectual property").

${ }^{11}$ The views of the bar are noted by various authors, e.g., Luke L. Dauchot, The Federal Circuit's De Novo Review of Patent Claim Construction: A Need for a More Balanced Approach, 18 Intell. Prop. L. Newsl. (Am. Bar. Ass'n Sec. on Intell. Prop., Chicago, Ill.), Fall 1999, at 1, 1 (arguing for the Federal Circuit to give greater deference to trial court interpretations); Ted D. Lee \& Michelle Evans, The Charade: Trying a Patent Case to All "Three" Juries, 8 TeX. InTELl. Prop. L.J. 1, 11-20 (1999) (characterizing the Federal Circuit as a "second jury" in patent cases); Paul R. Michel, The Court of Appeals for the Federal Circuit Must Evolve to Meet the Challenges Ahead, 48 AM. U. L. REv. 1177, 11861200 (1999) (addressing oft-cited practitioner concerns); Douglas D. Salyers, The Paper Side of Jury Litigation in Patent Cases-Don't Become Just Another Statistic in The Federal Circuit, in Patent Litigation 1999, at 557, 566-88 (PLI Intell. Prop. Course, Handbook Series No. G-572, 1999).

${ }^{12}$ The reported opinions of judges, other than those on the Federal Circuit, have been largely negative. One district court judge has stated publicly that the Federal 
design of the patent system. ${ }^{13}$ Yet the analysis of its design requires careful evaluation, and most of this literature, while often illuminating, has not been empirically grounded. ${ }^{14}$

This Article provides important insights into this question by presenting the results of a novel empirical study of judicial performance. The findings suggest that the Federal Circuit is a court in a period of significant transition-one driven by an ongoing effort to meet the requirements of its special mandate and by important changes in court personnel. The Federal Circuit has perhaps not yet succeeded in fulfilling its mandate, though the present trajectory of its jurisprudence holds out the promise that it ultimately will do so.

Our contribution to the debate surrounding the efficacy of the patent administration system offers two features that do not presently exist in the contemporary literature. First, the analysis is systematic and empirical, synthesizing all relevant judicial pronouncements across the approximately seven-year time period of the study, rather than using scattered or individual case results. ${ }^{15}$ Second, the study focuses squarely on the methodological approach of the Federal Circuit,

Circuit is full of "little green men who don't know Tuesday from Philadelphia." Victoria Slind-Flor, The Markman Prophecies, IP WORLDWIDE, March 13, 2002, at 28, 30 (quoting Judge Samuel Kent of the Southern District of Texas); see also id. ("Frankly, I don't know why I'm so excited about bringing this [patent case] to closure. It goes to the Federal Circuit afterwards. You know, it's hard to deal with things that are ultimately resolved by people wearing propeller hats."' (quoting Judge Kent in O.I. Corp. v. Tekmar Co., No. 95-CV-113 (S.D. Tex. June 17, 1996))).

${ }^{13}$ Note also that everyone seems to agree (without much discussion) that patents have become, on balance, more valuable assets under the Federal Circuit's tutelage. See, e.g., Donald S. Chisum et AL., PRinciples of Patent Law 33-34 (2d ed. 2001). But strength or scope, of course, is not the same as consistency; it is entirely possible that the Federal Circuit has increased the "mean" strength of a patent (its likelihood of being upheld, its enforceable scope, etc.), while maintaining the earlier variance and unpredictability in outcomes.

${ }^{14}$ There are, however, several notable examples of empirical studies on this subject, such as Chu, supra note 10; Lemley, supra note 10; Kimberly A. Moore, Are District Court Judges Equipped to Resolve Patent Cases?, 15 HARV. J.L. \& TECH. 1 (2001).

${ }^{15}$ There is, of course, absolutely nothing wrong with doctrinal analysis using selected (i.e., important or symbolic) judicial opinions. Our point is to note that the systematic nature of this study offers insights that are not captured by the literature. Prior analyses of the Federal Circuit's approach to claim construction include: Duffy, supra note 10; Nard, Process Considerations, supra note 10; Nard, Claim Interpretation, supra note 10; Rai, supra note 9; Rai, supra note 10; John M. Romary \& Arie M. Michelsohn, Patent Claim Interpretation After Markman: How the Federal Circuit Interprets Claims, 46 AM. U. L. REV. 1887 (1997); John R. Thomas, Of Text, Technique, and the Tangible: Drafting Patent Claims Around Patent Rules, 17 J. MARShall J. COMPUTER \& INFO. L. 219 (1998); Gwendolyn Dawson, Note, Matchmaking in the Realm of Patents: A Call for the Marriage of Patent Theory and Claim Construction Procedure, 79 TEX. L. REV. 1257 (2001). 
rather than simply counting appellate results (i.e., reversal rates). ${ }^{16}$ By looking (a) systematically and (b) at the expressed methodological approach, this study offers an unprecedented opportunity to evaluate the success of the court in its role as the arbiter of the patent law.

The study reported here analyzes the Federal Circuit's recent jurisprudence of claim construction - the interpretation of language defining a patent's scope-as a window into judicial performance. ${ }^{17}$ Specifically, the study analyzed the court's methodological approach to claim construction in all written opinions since the April $1996 \mathrm{Su}-$ preme Court opinion in Markman $I I^{18}$ using a specially developed casecoding technique that captured both general methodology and the strength of its form. The collected data was used to conduct descriptive statistical analyses, which revealed the Federal Circuit's overall methodological approaches, discernible trends over time, and the methodology of the court's judges on an individual basis.

The data reveals a sharp division within the court between two distinct methodological approaches (which we term "procedural" and "holistic," respectively), each of which leads to distinct results. ${ }^{19}$ Specifically, we find that the Federal Circuit utilized the procedural approach in $63 \%$ of the cases and the holistic approach in the remaining $37 \%$. During the time period of our study, the procedural approach gained favor with the court in a gradual, though statistically significant, fashion. We also find that the Federal Circuit's jurisprudence became increasingly polarized during this time, with a significant

${ }^{16}$ For examples of such studies, see Chu, supra note 10; Moore, supra note 10 . As Part I notes in more detail, such result-studies, while descriptively quite valuable, do not allow many conclusions to be drawn concerning the judicial approach taken by the Federal Circuit.

${ }^{17}$ Claim construction is a uniquely appropriate doctrine for this sort of analysis, in particular because this area is where the court's mandate for uniformity and predictability is at its most explicit and broadly recognized. Infra Part I.

18517 U.S. 370 (1996)

19 The procedural approach is characterized by adherence to a relatively strict rules-based hierarchy of interpretive sources, with a particular emphasis on the ordinary meaning of disputed patent claim language. The holistic approach is a far less structured analysis, utilizing the array of possible interpretive information in a flexible, case-specific fashion. Infra Part II.B.

These dichotomous categories were developed through an analysis of the jurisprudence itself, which reveals that the form of methodological approach uniformly drives disputes over claim construction (though we are the first to formally define the dueling analytic methods). The data suggests that differences in methodological approach underlie both Federal Circuit reversals of district court claim constructions as well as dissenting and concurring opinions produced by members of the court itself. Infra Part II.E.3. 
increase in the use of "strong" forms of each methodological approach. ${ }^{20}$ These trends can be attributed, we believe, to increased activity among judges who typically author strong methodological opinions, as well as to the appointment of two strongly Proceduralist judges (Judges Linn and Dyk) to the court in 2000.

Our findings also indicate that claim construction at the Federal Circuit is panel dependent. ${ }^{21}$ That is, the data reveals that the composition of the panel that hears and decides an appeal has a statistically significant effect on the claim construction analysis. Specifically, we find that individual judges vary widely in their methodological approach to claim construction, ${ }^{22}$ and that the distribution of the judges allows useful classification into three groups: the "Proceduralists" (i.e., those preferring procedural analyses), the "Holistics" (i.e., those preferring holistic analyses), and a middle group, the "Swing Judges." Panel participation by members of both the Proceduralist and Holistic groups is statistically related to the form of claim construction analysis. ${ }^{23}$ In addition, the differential odds of a particular methodological approach can be calculated with $95 \%$ statistical significance for half (i.e., six) of the currently active Federal Circuit judges. ${ }^{24}$

The totality of these results adds substantially to the contemporary analysis of the patent administration system-as well as offers unprecedented tools for the analysis of patent claims, patent disputes, and (especially) appellate proceedings at the Federal Circuit. Institutionally, the Federal Circuit appears to be a court in the midst of broad transition, especially in terms of personnel. The "new" Federal Circuit that is now emerging-a court that is more rules-based and consistent-is already having a measurable impact on patent jurisprudence.

The findings also suggest a number of policy implications for the court's efforts to meet its mandate. We recommend that the court recognize the importance of methodology and move to standardize

\footnotetext{
${ }^{20}$ These parallel trends-a gradual change in methodological approach and increasing polarization-are likely to account for the high reversal rates found by other studies, see Chu, supra note 10; Moore, supra note 14, as well as the sense of concern among court observers, see supra notes 10-12.

${ }^{21}$ Panel dependency is a frequent criticism of the Federal Circuit-a critique that is consistently refuted by the judges themselves. Infra Part III.D.

${ }_{22}$ As authors, the judges utilize the holistic methodological approach in a frequency range from $7.1 \%$ to $69.0 \%$. Infra Part III.C.

Infra Part III.D.

${ }^{24}$ The remaining judges have no statistically significant effect on the claim construction analysis. Infra Part III.D.1.
} 
the procedural methodological approach-the evidence suggests that the procedural approach is inherently more consistent than holistic analyses. Individual judges also have an important role to play in enforcement and evangelism.

In our view, whether the Federal Circuit is succeeding is a question that remains remarkably open. Little in these results would lead one to conclude that the court has been an unqualified success in bringing additional consistency, uniformity, and predictability to the patent law. But at the same time, many findings are unquestionably encouraging, suggesting that the court's effort to meet its mandate is both well underway and moving in the right direction.

This Article has four main parts. Part I sets forth the doctrinal and theoretical background of the Federal Circuit and its special mandate in the area of the patent law: an institutional framework that requires the court to develop its jurisprudence in a clear, coherent, and predictable manner. This mandate is particularly relevant in the area of claim construction, where characteristics of the analysis and policy-laden determinations by both the Supreme Court and the Federal Circuit fundamentally require jurisprudential consistency. This, in turn, suggests that claim construction is perhaps the best possible locus of inquiry into the success or failure of the court in achieving its mission.

The design of the study is set forth in detail in Part II, which describes the research methods used, including the development of the case-coding instrument, the selection of the case population, and the coding techniques.

In Part III, the results are presented, consisting of four basic inquiries. The first is the overall response of the court to the Markman II mandate, measuring the total content of the relevant jurisprudence. The second analytic section reviews trends during the period of the study and considers which factors may be driving the observed changes. A third section reports the methodological approach of individual Federal Circuit judges, describes the analytical camps or factions that exist among the judges, and ranks the judges according to consistency in methodological approach. The judge-based information is used in the fourth section to demonstrate the panel dependency in claim construction at the Federal Circuit, both in terms of the judge groups developed above and in terms of the individual judges themselves. Finally, policy implications and proposed reforms are described in Part IV. 


\section{Designing The Federal Circuit: A Doctrinal AND THEORETICAL BACKGROUND}

By now, it is widely recognized that the United States Court of Appeals for the Federal Circuit has firmly placed its imprimatur on the administration of the United States patent system. With impressive speed and agility, this court, in two decades, has gone from creation to domination-broadening, strengthening, and shaping the patent law in innumerable ways. Of course, power and recognition foster controversy and criticism; indeed, the persistent questions concerning the ultimate success of the legal centralization embodied in the Federal Circuit are what inspire this work.

Section A provides the foundation for the study. It describes the basic premise behind Congress's creation of the Federal Circuit-the expectation that the centralization of legal authority would yield a more effective development of the patent law. As the following pages describe, this mandate for clarity, coherence, and predictability is perhaps at its strongest in the particular doctrinal area of claim construction-the process of interpreting patent claim language. This special mandate provides a compelling opportunity to evaluate the Federal Circuit directly-on its own terms, in its efforts to meet the expectations that produced it.

\section{A. The Theory of the Federal Circuit}

We start from the premise that the important story to be told about the rise of the Federal Circuit is not one of accident, incompetence, or judicial tyranny-though at least some commentators suggest as much ${ }^{25}$-but of calculated institutional design refined over two decades. ${ }^{26}$ There is little doubt about what Congress believed it was doing when it passed the Federal Courts Improvement Act (FCIA) in

${ }^{25}$ See, e.g., LAWREnCE Lessig, The Future Of IdeAs 208-10 (2001) (criticizing the Federal Circuit for broadening the scope and subject matter of patents without authorization); Declan McCullagh, Left Gets Nod from Right on Copyright Law, CNET NEws.COM (Nov. 20, 2002), at http://news.com.com/2100-1023-966595.html (““A specialized court tends to see itself as a booster of its specialty. .. Patents are clogging retail commerce on the Internet, and software (patents) in particular are apparently impediments to software development.'” (quoting Judge Richard Posner)); see also Rai, supra note 9, at 1035-65 (arguing that the present institutional design is substantially flawed).

${ }^{26}$ See, e.g., Rai, supra note 9, at 1038 n.4 (noting the conscious choice of the Federal Circuit as the key legal player in the patent system). 
$1982,{ }^{27}$ establishing the Federal Circuit and designating that court as the exclusive venue for patent appeals, whether from decisions of the U.S. District Courts or the U.S. Patent and Trademark Office (PTO). Unifying appellate jurisdiction under a single court was seen as an effective, albeit untested, ${ }^{28}$ response to the widespread perception that the legal infrastructure of patent law was not being effectively managed. Congress was presented with reports demonstrating that the PTO was essentially "freelancing" with respect to the standards of patentability, resulting in an increasing divergence in the legal framework applied by the judiciary and the PTO and an erosion of the statutory presumption of validity that attached to patents upon issue. ${ }^{29}$ Perhaps even more important was the perception that patent cases received quite distinct treatment throughout the regional circuits, yielding confusion about the ability to enforce patent rights, as well as rampant forum shopping (and related litigation). ${ }^{30}$ For its part, the Supreme Court had shown little interest in managing the patent lawprobably because of increasing demands on its docket and a general perception by the judiciary that patent cases were particularly troublesome or difficult. ${ }^{31}$

Thus, from its inception, the Federal Circuit's exclusive appellate jurisdiction over the patent law ${ }^{32}$ has been based on the following line

\footnotetext{
${ }^{27}$ Federal Courts Improvement Act of 1982, Pub. L. No. 97-164, 96 Stat. 25 (codified as amended in scattered sections of 28 U.S.C.).

${ }^{28}$ See Dreyfuss, supra note 6, at 3 (describing FCIA as "a sustained experiment in specialization”).

${ }^{29}$ See id. at 6 ("Since [the PTO] ... was free to develop its own notions of patentability but could not impose them on other federal courts, its decisions did not command the respect of the judiciary.").

${ }^{30}$ See Charles W. Adams, The Court of Appeals for the Federal Circuit: More than a National Patent Court, 49 Mo. L. REV. 43, 55-57 (1984) (noting the regional circuits' disparate standards for patentability); Dreyfuss, supra note 6, at 6-7 (describing the problems with regional circuit review).

31 See Adams, supra note 30, at 45 ("With an increasing volume of petitions for certiorari, the Supreme Court is less able to resolve conflicts between the circuits."); Dreyfuss, supra note 6 , at 6 ("Perhaps because of its own docket problems and its lack of expertise, the Supreme Court rarely reviewed the patent law decisions of the regional circuits.").

${ }^{32}$ The Federal Circuit has also been assigned jurisdiction over appeals in a number of other substantive areas, including trademarks, international trade, government contracts, federal claims, and federal civil service disputes. 28 U.S.C. $\$ 1295$ (a) (2000). Indeed, Congress made it clear that it did not consider the court to be "specialized" due to the diversity of its assigned subject matter. See H.R. REP. No. 97-312, at 19 (1981) ("The proposed new court is not a 'specialized court.' Its jurisdiction is not limited to one type of case, or even to two or three types of cases. Rather, it has a varied docket spanning a broad range of legal issues and types of cases.").
} 
of reasoning: (1) the court, in its centralized role, would act as the manager and developer of the patent law, ${ }^{33}$ and (2) the imposition of such a structure would yield a clearer, more coherent, and more predictable patent doctrine, reduce or eliminate forum shopping, and at least rationalize-if not strengthen-the patent grant. ${ }^{34}$

While the ultimate success of this foray into centralized judicial authority for the patent law is uncertain (and, indeed, the subject of this Article), Congress's structural goals certainly seem to have been realized. There is little doubt that the Federal Circuit has moved briskly into its role as the manager and developer of the patent doctrine. ${ }^{35}$ Professor Dreyfuss, in a survey of the Federal Circuit's early development, noted that the court seized the jurisprudential initiative in a number of areas, including the standard for obviousness, the availability of remedies, and procedural issues, though her conclusions regarding the success of these efforts were mixed. ${ }^{36}$ It is widely perceived that patents are more valuable today than before $1982,{ }^{37}$ and, given the appellate structure, the results in any case are not affected by the regional circuit of origin. In short, the institutional design envisioned by Congress has been realized: the Federal Circuit has, in a variety of doctrinal areas, assumed its central management

33 See, e.g., H.R. REP. NO. 97-312, at 20-23 (1981) (detailing the court's primary role in increasing uniformity in patent law); see also Adams, supra note 30, at 62 (asserting that the FCIA "has enhanced uniformity in patent law by providing a central forum for deciding patent appeals"); Dreyfuss, supra note 6, at 7 (noting that FCIA attempted to resolve the problems of PTO arbitrariness and divergence of law across regional circuits "by creating a single forum to hear appeals from most patent disputes").

${ }^{34}$ See H.R. REP. NO. 97-312, at 20-23 (1981) (predicting these benefits with the advent of the new court); S. REP. NO. 97-275, at 5 (1981), reprinted in 1982 U.S.C.C.A.N. 11, 15 (expecting that the new court would "increase doctrinal stability" and "produce desirable uniformity" in patent law); see also Adams, supra note 30, at 62 (stating that, through greater uniformity in patent law, the FCIA "thus has decreased the incentive for litigants to engage in forum shopping"); Dreyfuss, supra note 6, at 5-7 ("According to proponents of [FCIA], channelling patent cases into a single appellate forum would create a stable, uniform law and would eliminate forum shopping. Greater certainty and predictability would foster technological growth and industrial innovation and would facilitate business planning.").

${ }^{35}$ See Janis, supra note 2, at 402 (noting that the Federal Circuit has an effective "monopoly over substantive patent law adjudication" since its creation in 1982).

${ }^{36}$ Dreyfuss, supra note 6 , at 7-22.

37 See CHISUM, supra note 13, at 24 ("The [Federal Circuit] ushered in a new approach to patent validity and defenses to infringement, resulting in a significant strengthening of the patent grant['s value] ...."); see also Michael J. Meurer, Controlling Opportunistic and Anti-Competitive Intellectual Property Litigation, 44 B.C. L. REV. 509, 519 (2003) ("[I]ntellectual property has become more valuable, and the number of patents, copyrights, and trademarks has increased rapidly.”). 
role. Whether the court has been successful in implementing this role to achieve the expected results underlying the Congressional action remains, of course, an open question.

\section{B. The Special Mandate of Claim Construction}

The Federal Circuit's mandate to develop patent doctrine in ways that promote clarity, coherence, and predictability is perhaps at its most powerful in the context of the court's claim construction jurisprudence. In addition to the general premise of legal centralization described above, several features of claim construction make this area of the law an especially important test for the Federal Circuit. In particular, we note below that the Supreme Court's decision in Markman $I I^{38}$ is best understood not merely for its allocation-of-authority principles, but for its prescriptive aspect, which was clearly directed at the Federal Circuit. This directive required that the jurisprudence of claim construction be developed to provide parties and (especially) district courts with the necessary tools to perform this complex analysis. As set forth below, this makes claim construction an especially apt doctrinal window through which to observe the performance of the Federal Circuit. But first, we briefly detour into a description of the essential features of the modern claim construction system. Readers familiar with this aspect of modern patent law may wish to skip the following subsection.

\section{A (Brief) Primer on Claim Construction}

Patent claims are, put simply, the textual description of what a patentee "claims" as her patented invention. ${ }^{39}$ They establish the basic boundaries of the patentee's right to exclude others from the marketplace and also determine whether the patentee receives a patent at all. As Judge Giles Rich once famously noted, in patent law, "the name of the game is the claim."

Claim "construction" or "interpretation," then, is the process of placing the language found in the claims into a meaningful context,

${ }^{38} 517$ U.S. $370(1996)$

3935 U.S.C. $\$ 112(2000)$.

${ }^{40}$ Giles S. Rich, Extent of Protection and Interpretation of Claims-American Perspectives, 21 INT'L REV. INDUS. PROP. \& COPYRIGHT L. 497, 499 (1990) ("The U.S. is strictly an examination country and the main purpose of the examination, to which every application is subjected, is to try to make sure that what each claim defines is patentable.

To coin a phrase, the name of the game is the claim."). 
given the circumstances. Sometimes claim language will be unexpectedly vague-for example, does the term "coupled" require a physical connection? ${ }^{41}$ On other occasions, the language is intentionally difficult-how flat is "generally flat"? ${ }^{42}$ In either case, the patent law's system of claim construction analysis guides the inquiry.

It is important to note that claim construction is undertaken by a variety of public and private actors. For example, the PTO necessarily interprets claim language when evaluating the patentability of an invention. ${ }^{43}$ Private parties are constantly interpreting patent claim language as well, either as an evaluation of potential infringement risk, the determination of the value of a licensing agreement, or as part of an investment decision. But the really important claim interpretations are those conducted by the courts, usually during infringement proceedings. $^{44}$

From an institutional design perspective, important features of the current claim construction scheme are:

1. Claim language is determined solely by judges, typically well in advance of trial during what are (tellingly) known as Markman hearings. ${ }^{45}$

2. A district court's claim construction is reviewed de novo on appeal to the Federal Circuit. No formal deference is given to the district court or, for that matter, the PTO. ${ }^{46}$ At this point,

${ }^{41}$ No-at least not in U.S. Patent No. 5,202,835 (issued Apr. 13, 1993), entitled "Trolling Motor With Heading Lock." See Johnson Worldwide Assocs. v. Zebco Corp., 175 F.3d 985, 992 (Fed. Cir. 1999) (holding that the meaning of the term "coupled' . . is not limited to a mechanical or physical coupling").

${ }^{42}$ Not a twelve-degree rise in U.S. Patent No. 5,456,202 (issued Oct. 10, 1995), entitled "Planing Boat Hull." See Schoell v. Regal Marine Indus., 247 F.3d 1202, 1208-09 (Fed. Cir. 2001) ("[A] twelve degree V-shape [keel] cannot be both V-shaped and generally flat.").

${ }^{43}$ The standard used by the PTO is the "broadest reasonable interpretation," which is not a standard present in the non-PTO context. In re Graves, 69 F.3d 1147, 1152 (Fed. Cir. 1995) (quoting DeGeorge v. Bernier, 768 F.2d 1318 (Fed. Cir. 1985)); see also U.S. PATENT \& TRADEMARK OfFice, MANuAl of PATENT EXAmining PROCEDURE $§ 2111$ (2003) ("During patent examination, the pending claims must be "given their broadest reasonable interpretation consistent with the specification." (quoting In re Hyatt, 211 F.3d 1367, 1372 (Fed. Cir. 2000))); infra note 142 (describing in further detail the PTO's use of the "broadest reasonable interpretation" standard).

${ }^{44}$ Some commentators, notably Professor Duffy, suggest that the PTO's constructions should be given increased deference, due to its technical competence and lower operating cost. Duffy, supra note 10, at 126-35.

${ }^{45}$ See, e.g., William F. Lee \& Anita K. Krug, Still Adjusting to Markman: A Prescription for the Timing of Claim Construction Hearings, 13 HARV. J.L. \& TECH. 55, 59 (1999).

${ }^{46}$ See Duffy, supra note 10, at 118 (explaining that the Federal Circuit has treated claim construction "as a purely legal question"). 
the Federal Circuit has never accepted any interlocutory appeals on issues of claim construction. ${ }^{47}$

From an operational perspective, the patent law contains a wide variety of "canons of construction" that purport to guide the analysis. ${ }^{48}$ As has been noted by the court itself, however, many, if not all, of these canons are contradictory and not especially useful. ${ }^{49}$ Indeed, it is the efforts to resolve the tension between a pair of these canons(a) that claims are to be interpreted in light of the specification and prosecution history and (b) that claims may not be modified beyond their actual language by reference to the specification or prosecution history-that creates the split in authority that forms the basis of this study.

Though the precise magnitude of its role is a matter of considerable debate ${ }^{50}$ it is clear that claim construction plays a major-and perhaps the major-role in patent infringement litigation. And with the gradual decline in favor of the doctrine of equivalents-a judicial doctrine allowing patentees to exclude others from making, using, and selling subject matter beyond the scope of, but "equivalent" to, their claims ${ }^{51}$ - there is reason to expect that the importance of claim interpretation will only increase.

${ }^{47}$ See, e.g., Nard, Process Considerations, supra note 10, at 372-74 (decrying the denial of interlocutory appeals). Many district court judges, however, simply enter summary judgment for one of the parties after construing the claims, creating a de facto interlocutory appeal. See John R. Lane \& Christine A. Pepe, Living Before, Through, and With Markman: Claim Construction as a Matter of Law, 1 BUFF. INTELL. Prop. L.J. 59, 64 (2001) ("[L]itigants have developed the practice of using preliminary injunctions and summary judgment motions to obtain early claim construction rules and possible pretrial Federal Circuit review of the district court's claim construction.”).

${ }^{48}$ See, e.g., Rexnord Corp. v. Laitram Corp., 274 F.3d 1336, 1341-48 (Fed. Cir. 2001) (describing the canons of construction the Federal Circuit employs in claim construction analysis).

${ }^{49}$ Indeed, the patent law features canons to avoid the use of canons. See, e.g., Autogiro Co. of Am. v. United States, 384 F.2d 391, 397 (Ct. Cl. 1967) ("In utilizing all the patent documents, one should not sacrifice the value of these references by the 'unimaginative adherence to well-worn professional phrases.'” (quoting Felix Frankfurter, Some Reflections on the Reading of Statutes, 47 CoLUM. L. REV. 527, 529 (1947))); see also Renishaw PLC v. Marposs Societa' per Azioni, 158 F.3d 1243, 1248 n.2 (Fed. Cir. 1998) (citing Karl N. Llewellyn, Remarks on the Theory of Appellate Decision and the Rules or Canons About How Statutes Are to Be Construed, 3 VAND. L. REV. 395, 401-06 (1950) (illustrating the tractability of canons of construction)).

${ }^{50}$ See, e.g., Markman I, 52 F.3d at 993 (Mayer, J., concurring) (asserting that claim construction often determines the outcome of patent cases).

${ }^{51}$ See, e.g., Warner-Jenkinson Co. v. Hilton Davis Chem. Co., 520 U.S. 17, 21 (1997) (addressing the claim scope available under the doctrine of equivalents). 
Thus armed with some general background information about patent claim construction, we can turn now to the details of the institutional arrangements and their implications.

\section{Markman and the Express Mandate}

It has been almost seven years since the Supreme Court's decision in Markman II set into place the basic structural design of the claim construction process. Holding that the Seventh Amendment's guarantee of a jury trial did not apply to the interpretation of the patent document, the Court made quite clear that the question was "exclusively within the province of the court. ${ }^{52}$ More important than the holding, however, was the reasoning. Justice Souter, writing for a unanimous Court, framed the issue in traditional (and traditionally narrow) Seventh Amendment terms: whether the right to a trial by jury existed under the English common law in the late eighteenth century. ${ }^{53}$ The Court noted that while patent infringement actions were unquestionably tried to juries during the relevant time period, the historical record was far less clear regarding the locus of decisionmaking on interpretation. The Court's historical analysis was-as one might imagine-substantially complicated on this point because patent claims (at least as we understand them now) did not exist until the early $1800 \mathrm{~s},{ }^{54}$ did not receive formal legal recognition until $1836,{ }^{55}$ and were not required of all patentees until $1870 .^{56}$ Thus, the court turned to the body of the patent document itself - the specification ${ }^{57}$-as a contemporaneous analogue. Surveying what it described as the "mere smattering" of relevant cases, ${ }^{58}$ the Court concluded that there was no evidence that eighteenth-century juries had interpreted patent documents and found it telling that "as soon as the English [courts] did begin to describe the construction of patent documents" in the early 1800 s, they indicated that the judge was the interpreter, not the jury. ${ }^{59}$

${ }^{52}$ Markman II, 517 U.S. at 372.

${ }^{53} I d$. at 376.

${ }^{54}$ See William Redin Woodward, Definiteness and Particularity in Patent Claims, 46 MicH. L. REV. 755, 758 (1948) ("Probably the first examples of real patent claims in the modern sense were contained in the patent granted to Robert Fulton on February 9,1811 , which included several separate statements in the form of claims.").

${ }_{55}$ Act of July 4, 1836, ch. 357, § 6, 5 Stat. 117, 119.

${ }_{56}$ Act of July 8, 1870, ch. 230, § 26, 16 Stat. 198, 201.

${ }^{57}$ In patent parlance, the "specification" is the document itself, which includes a written description, the claims, and often, drawings or diagrams.

${ }^{58}$ Markman II, 517 U.S. at 379-81.

${ }^{59} I d$. at 382 . 
Thus, the Court rejected the argument that the Seventh Amendment guaranteed the role of the jury in claim construction. ${ }^{60}$

Significantly, Markman II here turns from description to prescription. That is, having found no constitutional reason to task the jury with claim construction, the Court-after noting that longstanding precedent (at least weakly and to some extent) supported an exclusive judicial role ${ }^{61}$-ultimately rested its decision on purely "functional considerations." ${ }^{\prime 2}$ These factors took two forms. The first was the Court's expectation that judges-by virtue of their special skills and experience, as well as the "highly technical" nature of patent claim construction and the "special doctrines" developed by the courts for their interpretation ${ }^{63}$ - were simply more likely to be better at the task than "jurors unburdened by training in exegesis." ${ }^{64}$ Second, the allocation of interpretive authority to judges was, the Court suggested, likely to promote the goals of intrajurisdictional certainty and uniformity. ${ }^{65}$ Whether the Court got it "right" when it analyzed these factors is obviously a matter of some debate, which has been widely

${ }^{60} I d$. at $383-84$.

${ }^{61}$ See id. at 384 n.10 ("[W]e conclude that our precedent supports classifying the question as one for the court ...."); see also id. at 387 (noting the "fine" line drawn between questions of interpretation and infringement, and the roles of the judge and jury, in nineteenth-century Supreme Court patent cases); $c f . i d$. at 388 (suggesting such precedent provided "no clear answers").

${ }^{62} I d$. at 388 .

${ }^{63} I d$. at 389 (quoting Woodward, supra note 54, at 765). The Court downplayed the influence of credibility determinations, which it described as "the jury's forte," in claim construction analyses, reasoning that credibility determinations would rarely be a deciding factor and that, to the extent they existed, they would be "subsumed within the necessarily sophisticated analysis of the whole document." Id.

${ }^{64} I d$. at 388 .

${ }^{65}$ The Court's discussion noted that it was especially concerned with uniformity of treatment concerning a particular patent-one that presumably might be litigated nearly contemporaneously in multiple jurisdictions. See id. at 390 ("[W]e see the importance of uniformity in the treatment of a given patent as an independent reason to allocate all issues of construction to the court."). By designating the interpretive issue as a matter of law, Markman II suggested that principles of stare decisis might serve to maintain intrajurisdictional uniformity prior to appellate review. See id. at 391 (noting that issue preclusion would be unavailable against new and independent infringement defendants). On this ground, however, the Court's concerns seem overstated; the district courts have used their discretionary case management tools to largely avoid any potential intrajurisdictional conflicts concerning the same patent. See, e.g., Genfoot, Inc. v. Payless ShoeSource, Inc., No. 03-398-SLR, 2003 WL 22953183, at*2 (D. Del. Dec. 3, 2003) (stating that transfer of venue to consolidate cases involving the same patents and parties is the "norm" because it "promote[s] judicial administration and consistency of results"). 
discussed and debated in the literature. ${ }^{66}$ However, from the perspective of institutional design, the importance of the Court's discussion is not the detailed analysis as much as the underlying assumptions (and, indeed, requirements) concerning the framework of the claim construction process. As an initial point, the Court was fairly explicit about its criteria for measuring the goodness of competing systems: correctness, ${ }^{67}$ uniformity, ${ }^{68}$ and certainty. ${ }^{69}$ Second, and perhaps more significantly, both functional factors identified by the Court share a unifying underlying principle: the existence of specific legal rules guiding the interpretation of patent claims. For example, in suggesting that judges were likely to be better at construing claims, the Court cited "special doctrines" relating to construction embedded in the law. ${ }^{70}$ Further, stare decisis-the strong judicial convention of adherence to existing judicial precedent-anchored the Court's argument that judicial decision making in this context would enhance uniformity and certainty. ${ }^{71}$ Thus, in both cases, Markman II's functionalist approach was largely based on the theory that allocating the interpretive task to judges would extend and enhance the development of legal rules guiding the construction of patent claims.

And yet the logic of Markman II clearly encompasses a prescriptive aspect as well. If the Court assigned claim construction to judges on the theory that doing so would result in the continued use and development of legal rules, then it follows that such legal rules (and their development) are not simply hortatory, but are instead a mandatory aspect of the institutional arrangements surrounding claim construction. In essence, the Markman II decision granted the judges the

${ }^{66}$ For example, the Court made an explicitly empirical assumption about the prevalence of conflicting expert testimony on claim construction. See Markman II, 517 U.S. at 389 (" $[\mathrm{I}] \mathrm{n}$ theory there could be a case in which a simple credibility judgment would suffice to choose between experts . . . [b] ut our own experience with document construction leaves us doubtful that trial courts will run into many cases like that.").

${ }^{67}$ See id. at 388 (noting that "judges often do [interpret] and are likely to do better [at interpreting]" written instruments).

68 See id. at 390-91 (discussing the benefits of uniform treatment of patents and citing the creation of the Federal Circuit as an example of the push for such uniformity).

69 See id. (discussing intrajurisdictional certainty).

${ }^{70} I d$. at 389 (quoting Woodward, supra note 54, at 765). This reasoning, of course, has the flavor of circularity about it: citing the existence and strength of judicially-created doctrine as a reason to allocate interpretive authority to judges. The Court here clearly assumed a stronger baseline in favor of judicial interpretation than it seemed to have acknowledged earlier in the opinion. See supra note 61 (citing the Court's acknowledgment that precedent provided "no clear answers").

${ }^{71}$ Markman II, 517 U.S. at 391. 
power to construe patent claims, but this grant was clearly conditioned on the use and development of legal-doctrinal "rules and tools" to provide clarity and uniformity in the treatment of interpretive issues. $^{72}$ Absent a uniform legal framework, the basic premise of the Court's functionalist analysis is absent.

Significantly, the Federal Circuit has, to no small extent, amplified the effect of the Supreme Court's prescription in Markman II. In Cybor Corp. v. FAS Technologies, Inc., ${ }^{73}$ an en banc court responded to the challenge. While the Cybor majority opinion, joined by nine judges, has been described as "unfortunate" and involving "strained reasoning" in the "manufacture [of] legal fictions," relatively few commentators have fully considered the logical framework underlying Cybor. This is understandable in part because the majority opinion focused almost entirely upon the question of whether claim construction is an inquiry of "fact" or "law" and, more particularly, upon whether Markman II stated a view on the matter. ${ }^{76}$ It is easy to criticize this form of analysis; even the Supreme Court in Markman II noted that divining the fact/law distinction is considerably less satisfactory than an analysis grounded in historical analogues and functional considerations. By declaring the interpretation of patent claims as "purely legal," the Cybor majority reasoned that no deference was due a district court's claim construction and that appellate review was to be conducted de novo. $^{78}$ Unfortunately, the Cybor majority did not base its argument on institutional design considerations, the instrumentally appropriate

${ }^{72} I d$. at $390-91$.

73 138 F.3d 1448 (Fed. Cir. 1998) (en banc).

${ }_{74}^{74}$ Duffy, supra note 10, at 119.

${ }^{75}$ Nard, Claim Interpretation, supra note 10 , at 35.

${ }^{76}$ See Cybor, 138 F.3d at 1455-56.

77 See Markman II, 517 U.S. at 378 ("[T] he sounder practice, when available, is to classify a mongrel practice [like claim construction] by using the historical method . . . ."); see also id. at 384 (noting the difficulty of drawing the fact/law distinction in claim construction); Cooter \& Gell v. Hartmarx Corp., 496 U.S. 384, 401 (1990) (observing the difficulty in distinguishing between factual and legal issues); United States v. McKinney, 919 F.2d 405, 419 (7th Cir. 1990) (Posner, J., concurring) (determining the standard of review on the basis of facts versus law would be "absurd"); Duffy, supra note 10, at 122-23 \& nn.51-53 (suggesting that Cybor's choice between standards of review "cannot be made on the basis of metaphysical distinctions between fact and law"); Gary Lawson, Proving the Law, 86 Nw. U. L. REV. 859, 863 (1992) (describing the historical convention of the fact/law distinction).

${ }^{78}$ Cybor, 138 F.3d at 1456 ("[W]e therefore reaffirm that, as a purely legal question, we review claim construction de novo on appeal ....”). 
location of this decision-making authority. ${ }^{79}$ Rather, as Professor Duffy has aptly noted, the opinion can really only be viewed as implicitly reinforcing the Federal Circuit as the superlative administrative player in the claim construction process. ${ }^{80}$ Thus, the Federal Circuit has not merely embraced the special mandate underlying the Markman II decision-it has reinforced it.

\section{A Look Inside: Claim Construction and the Federal Circuit}

The preceding Sections have demonstrated that the Federal Circuit, by conscious institutional design, has been placed at the center of the patent law, and that claim construction, in particular, represents a doctrinal area of special significance for implementation of the court's mandate. Indeed, it would be difficult to understate this issue's centrality to the court. The premise of the institutional design scheme established by Congress, amplified by the Supreme Court in Markman II, and executed by the Federal Circuit is that the court should utilize its dominant role in claim construction to build the rules and tools so that district courts, patentees, and interested members of the public can confidently analyze claim construction issues.

79 See id. at 1477 (Rader, J., dissenting) (arguing that "the trial judge enjoys a potentially superior position to engage in claim interpretation" over the Federal Circuit).

${ }^{80}$ Duffy, supra note 10, at 123 ("The majority's holding in favor of de novo review must be viewed as an implicit determination [regarding institutional design].”). Duffy (and others) have argued that the choice of de novo review in Cybor undermined the goal of uniformity, perhaps in an effort to increase procedural efficiency. See id. at 124 ("Both deferential and de novo standards trade one set of costs for another."); see also Cybor, 138 F.3d at 1476 (Mayer, C.J., concurring) (explaining that, as a matter of law, claim interpretation is subject to a $50 \%$ reversal rate on appellate review, which creates uncertainty and weakens the benefits of Markman I). Yet, it is not necessarily the case that a de novo standard of review will either undermine certainty or reduce the efficiency of the system. De novo review need not be viewed as an invasive mechanism by which the appellate court can put its stamp of approval on every decision. Instead, it can be viewed as a means to an end: a tool with which to develop and enforce rules governing claim construction. That is, if the de novo review process allows the Federal Circuit to establish clear guidelines for the interpretation of patent claims, certainty and efficiency would be enhanced, not diminished. Clear rules would allow district court judges to implement claim constructions with greater confidence, allow the parties to better evaluate their chances of success (both post-judgment and pre-litigation), and perhaps most significantly, result in patentees drafting clearer claims prior to a patent's issue. This general point-that patent rules are often best considered as ex ante incentive-based mechanisms-is one that one of us has made elsewhere. See R. Polk Wagner, Reconsidering Estoppel: Patent Administration and the Failure of Festo, $151 \mathrm{U}$. PA. L. REV. 159, 243 (2002) ("In the patent context, featuring significant informational challenges and costly ex post determinations of liability, a focus on the ex ante effects of any particular legal rule seems especially appropriate.”). 
In addition, as noted above, particular features of claim construction make the doctrine especially relevant to considerations of institutional design, such as:

1. It is an excellent test of how the Federal Circuit uses its authority. Because of the issue's status as a question of law and the lack of any statutory or Supreme Court guidelines (other than Markman II's express mandate to develop guidelines), the court is uniquely in control of the establishment and implementation of claim construction procedures.

2. Claim construction is perhaps the central issue in any analysis of a patent-whether conducted privately, in connection with an application to the PTO, or during litigation. Because claim construction is often (if not always) dispositive, it is almost always argued, litigated, and disputed.

3. Largely because of the previous two factors, the Federal Circuit case law on claim construction is extensive, allowing for the development of a large dataset.

Where, as here, the query of interest is whether (and how) the Federal Circuit is adequately responding to its congressional mandate (and, in particular, the special prescriptions related to claim construction), the best analytic strategy is to evaluate the relevant doctrine directly, seeking to measure the court's progress towards the goals of clarity, coherence, and predictability within the administration of the patent law. The court's claim construction jurisprudence thus provides a rich resource by which to objectively describe the success, to date, of the Federal Circuit.

\section{STUdy DESIGN}

Having identified claim construction as perhaps the most relevant doctrinal area for evaluating the Federal Circuit's managerial role in the U.S. patent system, this Part turns to the details of study design, starting with the choice of judicial opinions as the source of data.

\section{A. Measuring Jurisprudence: Court Opinions as Data}

A key design choice faced at the outset concerned the identification of a source of information that allowed the sort of systematic analysis needed for this study. There are several ways one might gather data about the nature of the Federal Circuit's claim construction jurisprudence. One option would be to conduct a survey of the judges, with questions relating to the sorts of reasoning or 
methodologies they use in conducting claim construction. Alternatively, one might survey patent practitioners and scholars, requesting information concerning the typicality of certain types of observed methodological approaches. Each of these options might provide information about the variable in question, but each also suffers from a number of validity problems, including the possibility of systematic bias, the difficulties in developing reliable survey instruments, and (for judicial surveys) the general unreliability of responses received from those persons under study. ${ }^{81}$ To avoid such pitfalls, this study evaluates the Federal Circuit's methodological approach to claim construction by measuring - that is, categorizing according to standardized criteria-the court's expressions of its methodology in the opinions accompanying judicial decisions. In other words, for the purposes of this study, written judicial opinions were treated as data sources. $^{82}$ Of course, mining a large number of judicial opinions to

${ }^{81}$ See Richard E. Nisbett \& Timothy DeCamp Wilson, Telling More Than We Can Know: Verbal Reports on Mental Processes, 84 PSYCHOL. REV. 231, 233 (1977) (noting that subjective reports about one's own experience and thinking are highly inaccurate); Wendy M. Rahn et al., Rationalization and Derivation Processes in Survey Studies of Political Candidate Evaluation, 38 AM. J. POL. SCI. 582, 595-96 (1994) (finding that self-reporting voters rationalize their preferences rather than describe the actual reasoning for their preferences).

${ }^{82}$ There are several other studies (albeit not in the patent area) that use similar techniques. See Gerard Anderson et al., When Courts Review Medical Appropriateness, 36 MED. CARE 1295, 1296-97 (1998) (coding and statistically analyzing judicial opinions in state and federal insurance coverage cases); Mark A. Hall et al., Judicial Protection of Managed Care Consumers: An Empirical Study of Insurance Coverage Disputes, 26 SETON HALL L. REV. 1055, 1056-59 (1996) (coding state and federal judicial opinions about health insurance disputes involving issues of medical appropriateness); Peter J. Hammer \& William M. Sage, Antitrust, Health Care Quality, and the Courts, 102 Colum. L. REV. 545, 553-59 (2002) (coding health care-related antitrust opinions for reasoning according to aspects of quality and nonprice competition); James A. Henderson, Jr., Judicial Reliance on Public Policy: An Empirical Analysis of Products Liability Decisions, 59 GEO. WASH. L. REV. 1570, 1586-89 (1991) (coding 2517 judicial opinions in products liability cases and analyzing the type and frequency of different forms of judicial reasoning); Peter D. Jacobson et al., The Role of the Courts in Shaping Health Policy: An Empirical Analysis, 29 J.L. MED. \& ETHICS 278, 280-86 (2001) (coding judicial opinions and assessing the relationship between types of judicial reasoning and case outcomes); Ann Juliano \& Stewart J. Schwab, The Sweep of Sexual Harassment Cases, 86 CORNELL L. REv. $548,549-50,555-60$ (2001) (conducting a statistical analysis of 650 judicial opinions in federal sexual harassment cases between 1986 and 1996); Andrew P. Morriss, Developing a Framework for Empirical Research on the Common Law: General Principles and Case Studies of the Decline of Employment-at-Will, 45 CASE W. RES. L. REV. 999, 1059-92 (1995) (studying the content of judicial opinions in the context of evolution of common law doctrine); Vicki Schultz \& Stephen Petterson, Race, Gender, Work, and Choice: An Empirical Study of the Lack of Interest Defense in Title VII Cases Challenging Job Segregation, 59 U. CHI. L. REV. 1073, 1089-95 (1992) (conducting a statistical analysis of federal judicial opinions between 1965 and 1989 in Title VII cases); Gregory C. Sisk et al., Charting the 
collect relevant information is not so different from what lawyers do every day. The difference here is that the data was collected more systematically and measured by more rigid criteria.

Note also that the overall goal of the project-providing direct insight into the contemporary questions of institutional design of the patent system-effectively precludes using case outcomes (i.e., affirmance or reversal rates) as the basis of measurement. ${ }^{83}$ To be sure, reversal rates between $30 \%$ and $50 \%$, as found recently in separate studies by Christian Chu and Kimberly Moore, might suggest problems in the jurisprudence of claim construction (or application thereof). ${ }^{84}$ Yet because the reversal rate describes the district courts' performance (albeit as measured by the Federal Circuit), it explains little about the Federal Circuit itself. For example, a high reversal rate could indicate that nonspecialized district courts are simply unsuited to the often complex technological task of claim construction. ${ }^{85}$ Or, the rates could reflect that the doctrinal rules are still in a "shaking out" period in the district courts and will decrease with increasing familiarity among trial judges. ${ }^{86}$ Or, perhaps, the high reversal rates could represent a widespread disconnect between the Federal Circuit and the district courts, resulting in the underuse or misuse of the relevant doctrine. Therefore, result-oriented statistical studies, while

Influence on the Judicial Mind: An Empirical Study of Judicial Reasoning, 73 N.Y.U. L. REV. 1377, 1383 (1998) (coding judicial opinions according to constitutional reasoning).

${ }^{83}$ But cf. Chu, supra note 10, at 1096-1106 (using the reversal rate to analyze trends in the Federal Circuit's claim construction jurisprudence); Moore, supra note 14, at 2-4, 11-17 (using the Federal Circuit's reversal rate to question the district court's ability to analyze claim construction). See also John R. Allison \& Mark A. Lemley, How Federal Circuit Judges Vote in Patent Validity Cases, 27 FLA. ST. U. L. REV. 745, 746-49 (2000) (analyzing results of decisions on validity); Donald R. Dunner et al., A Statistical Look at the Federal Circuit's Patent Decisions: 1982-1994, 5 FED. CIR. B.J. 151, 153-56 (1995) (analyzing the proportion of certain results-invalidity, infringement, etc.-in Federal Circuit precedent); Kimberly A. Moore, Judges, Juries, and Patent Cases-An Empirical Peek Inside the Black Box, 99 MICH. L. REV. 365, 369-74 (2000) (analyzing results of jury trials in patent cases).

${ }^{84}$ See Chu, supra note 10, at 1097-1100 (positing that a reversal rate of 50\% means the losing party is unlikely to settle without appeal); Moore, supra note 14, at 38 ("The $33 \%$ reversal rate of district court claim constructions suggests that judges are not, at present, capable of resolving these issues with sufficient accuracy.").

${ }^{85}$ For a similar conclusion, see Chu, supra note 10, at 1106; see also Moore, supra note 14 , at 3 .

${ }^{86}$ Chu dismisses this as "unlikely" given the role of patent-specific practitioners in informing judges. Chu, supra note 10 , at 1106 . But the point here is not that the trial courts literally do not know the appropriate rules, but that their unfamiliarity and inexperience in using them (which would be reflected among all parties) could increase the variability of the decisions. 
obviously valuable for evaluating the performance of the district courts, should not be taken as establishing a causal link to Federal Circuit doctrine or methodology. ${ }^{87}$

This study thus utilizes the court's jurisprudence itself as the relevant data source, measuring aspects of the Federal Circuit's decision making as expressed in written judicial decisions. Given the object of the study-to analyze whether the court is effectively meeting its mandate for developing and managing a clear, coherent, and predictable jurisprudence-measuring the jurisprudence is most likely to provide the insights we seek.

Of course, choosing to use judicial opinions as data sources to measure judicial reasoning or methodology has a number of implications. Consider the following oft-cited concerns and limitations about using judicial opinions for systematic study:

- Unobserved Reasoning. Analyzing the content of judicial opinions assumes that the expression in a given opinion accurately reflects the actual process by which the result was reached. There is clearly at least some reason to question this assumption, ${ }^{88}$ if for no other reason than, as noted by Edward Rubin, the author of the opinion is primarily concerned with "justify[ing] her conclusion by showing that it proceeds from accepted sources by legitimate, properly argued steps." ${ }^{, 9}$

- Selection Bias. Judicial opinions, and in particular appellate court opinions, clearly do not represent the universe of disputes; it is therefore possible that the cases which generate a judicial opinion contain some systematic bias. For example, it is possible that claim constructions conducted by the Federal Circuit concern particularly complex technology or are the result of especially poorly drafted claims. ${ }^{90}$ Further, even though

\footnotetext{
${ }^{87}$ For example, Chu notes that his study of the results of claim construction reviews provides little help in evaluating the reasons that reversal rates are at any particular level. Id. at 1106-07.

${ }^{88}$ See, e.g., William M. Sage, Judicial Opinions Involving Health Insurance Coverage: Trompe L'Oeil or Window on the World?, 31 IND. L. REV. 49, 61-68 (1998) (identifying small sample size, long time lags, selection bias, publication bias, and unstated rationales as the limitations of a judicial dataset).

${ }^{89}$ Edward L. Rubin, The Concept of Law and the New Public Law Scholarship, 89 MiCH. L. REV. 792, 801 (1991).

${ }^{90}$ The authors do not believe this to be the case here. The population of opinions cover a huge variety of technologies, and while the quality of a patent claim is difficult to discern-especially when it is the subject of major litigation-neither coder observed systemic problems with claim quality.
} 
the dataset contained all written opinions-even those designated as "unpublished" or "non-precedential" by the court-it could not contain those decisions by the Federal Circuit that did not result in an opinion. ${ }^{91}$

- Strategic Behavior. In analyzing the output of judicial opinions, this study did not seek to account for various inputs that might have affected the outcome or reasoning, such as the quality of arguments, strategic choices by parties, or even strategic behavior by judges. ${ }^{92}$ A particular concern relevant to this study is the possibility that the judicial reasoning expressed in an opinion may be substantially affected by the arguments and methodologies employed by the litigants. For example, both litigants may, for strategic reasons, advocate similar methodological approaches (although seeking different results), making it more likely that the court would adopt such an approach. For this reason, it is perhaps unrealistic to view such opinions as truly independent expressions of methodology or reasoning.

While the concerns described above are at least potential limitations on the utility of this study, given the general hypothesis being tested, there are reasons to expect that these problems are less significant than might otherwise be the case. Recall that this study seeks to determine whether the Federal Circuit has developed a workable set of claim construction guidelines-the "rules and tools" mandated by the Supreme Court in Markman II and acknowledged in Markman I and Cybor. ${ }^{93}$ In particular, note that the object of the study is not the underlying methodological view of the Federal Circuit judges but the content of the relevant jurisprudence. In this respect, then, this study differs from many similar studies which seek to extract information (for example, the role that background factors may play in influencing judicial reasoning ${ }^{94}$ or the general use of health-care quality and other non-price factors in market-based analyses ${ }^{95}$ ) distinct from the expressed text of the opinions. Thus, for example, concern about the

\footnotetext{
${ }^{91}$ See FED. R. APP. P. 36 (permitting judgments to be rendered without an opinion).

${ }^{92}$ See, e.g., Richard A. Posner, What Do Judges and Justices Maximize? (The Same Thing Everyone Else Does), 3 SuP. CT. ECON. REV. 1, 23-30 (1993) (describing how judges' motivations can affect judicial decisions).

${ }^{93}$ Supra notes 7-8 and accompanying text; see also supra text accompanying notes 72-80.

${ }^{94}$ Sisk et al., supra note 82, at 1385-92, 1415-30, 1451-80.

${ }^{95}$ Hammer \& Sage, supra note 82, at 609-36.
} 
unobservability of the "true" reasoning of the judges is mitigated by the understanding that these unobservable aspects are not, by design, involved in evaluating the validity of the hypothesis. Likewise, while selection bias is undoubtedly a generalized problem with any sort of case-based research, the population of cases of relevance here (those which provide information to other institutional players) are precisely those contained in the dataset. There is perhaps somewhat more cause for concern regarding the possibility of bias in the dataset due to strategic factors-especially those that might impact the way that the methodological decision making is described in the opinions. However, even here a similar qualification holds true: because the goal is to systematically evaluate the content of the jurisprudence, factors that may have distorted the body of the law will be reflected in both the study results and the actual guidance provided by the cases. ${ }^{96}$ Accordingly, while the possibility that these issues may affect our study's results cannot be eliminated, any major impact seems unlikely. (There are, of course, significant limitations to this study due to other factors, as noted in the following Sections.)

\section{B. Procedural Versus Holistic: Selecting Measurement Criteria}

Perhaps the most significant design choice in this study was the determination of the criteria by which the object of measurementthe methodology expressed in the relevant judicial opinions-was to be described. Given the complete absence of similar studies in the patent context, the development of measurement criteria required some substantial innovation; as a result, attempts were made to ensure substantial conformance with appropriate scientific norms. ${ }^{97}$ The basic question, of course, was how to categorize methodological approaches to the claim construction problem. In particular, given the object of the study, the inquiry was whether there were possible methodological characteristics, ascertained from a sampling of the cases, that were sufficiently distinct as to allow for reliable categorization. ${ }^{98}$

\footnotetext{
${ }^{96}$ Thus, to the extent that systemic bias in expressions of methodology may exist due to the parties' arguments and approaches, perhaps one implication of the study is that judges should seek to avoid simply responding to parties' arguments and instead should view each opinion as a contribution to the wider jurisprudence.

${ }^{97}$ See Lee Epstein \& Gary King, The Rules of Inference, 69 U. CHI. L. REV. 1, 80-97

(2002) (describing the importance and evaluation of measurement criteria).

${ }^{98}$ See id. at 83-87 (discussing reliability).
} 


\section{A Review of the Literature}

An initial source for developing possible criteria was the relatively large post-Markman II scholarly literature on claim construction, under the theory that perhaps academic consensus and prior research could inform our inquiry. A review of that work revealed relatively few serious efforts to broadly describe features of the Federal Circuit's claim construction methodologies, at least in a manner relevant to the tasks here. One proposal was the distinction between what Professor Craig Allen Nard described as "pragmatic textualism" and "hypertextualism." ${ }^{99}$ As set forth by Nard, the distinction between these methodologies is primarily on the basis of "view[s] of judicial power" and is reflected in differing approaches to the standard of review and the treatment of extrinsic evidence. ${ }^{100}$ In Nard's view, "pragmatic textualists" freely consider information concerning the accepted meanings of particular terms in the relevant fields while "embracing the importance of textual fidelity and internal coherence," whereas "hypertextualists" eschew any contextual basis for determining the meaning of claim terms. ${ }^{101}$ Thus, it appears that the distinction Nard would draw involves two dimensions: the first is between a methodology that admits at least some forms of extrinsic evidence for context (pragmatic textualism) and one that does not (hypertextualism), and the second is between a methodology that offers at least some measure of deference to district court interpretations (pragmatic textualism) and one that sticks to de novo review (hypertextualism). This categorization approach was considered against a sample of the judicial opinion dataset, but ultimately was rejected. First, intuition and experience with the relevant jurisprudence suggested that the pragmatic/hypertextualist differences would likely be difficult to discern across the number of opinions evaluated in this study. Both of Nard's distinctions-the use of contextual extrinsic evidence and the standard of review-appear to be matters of settled law and thus show remarkable uniformity. ${ }^{102}$

${ }^{99}$ Nard, Claim Interpretation, supra note 10, at 4-6.

${ }^{100}$ Id. at 5-6.

${ }^{101} I d$.

102 As should be evident from the discussion in Part I of this Article, the standard of review question has been entirely settled since Cybor in 1998 and virtually settled since Markman I in 1995. In fact, the en banc court in Cybor noted only four cases that it considered even arguably inconsistent with the de novo standard of review established by Markman I. Cybor, 138 F.3d 1448, 1456 (Fed. Cir. 1998). Thus, reliably observing distinctions between opinions on the basis of the standard of review would appear to be extraordinarily difficult. See, e.g., Nard, Claim Interpretation, supra note 10, at 28 (noting that Cybor resolved this issue). 
Accordingly, it was extremely difficult to discern the proposed methodologies from the written opinions, even some of those discussed extensively in the text. ${ }^{103}$

We note that another academic effort, while not seeking to draw broad conclusions regarding claim construction jurisprudence, dovetailed far better with our initial review of the opinion dataset. In Patent Claim Interpretation After Markman: How the Federal Circuit Interprets Claims, ${ }^{104}$ John Romary and Arie Michelsohn sought to present a positive account of the court's claim construction jurisprudence. ${ }^{105}$ In doing so, they noted tensions in the case law concerning the emphasis given to the "ordinary meaning" of the claims, ${ }^{106}$ and the utilization of

A potentially more fruitful line of difference concerns the use of contextual (in patent parlance, "extrinsic") evidence to inform the meaning of the claim language. But again this distinction seems quite difficult to discern in the case law. To the extent that there was doctrinal rigidity in the jurisprudence, see Vitronics Corp. $v$. Conceptronic, Inc., 90 F.3d 1576 (Fed. Cir. 1996), it is unclear whether it actually prevented the consideration of important contextual evidence; and this rigidity appears not to exist in more current case law, which is replete with references to dictionaries, technical and otherwise, as well as the increasing use of experts, see Pitney Bowes, Inc. v. HewlettPackard Co., 182 F.3d 1298 (Fed. Cir. 1999). To be sure, there is a clear distinction concerning the hierarchical status of this type of information, and that distinction informs this study's measurement criteria. But there does not seem to be a reliable categorization according to the consideration of this information.

We should be clear that this discussion is not meant as a critique of Nard's discussion of competing interpretive theories (though we suspect we disagree on many points). To a large degree, Nard's project is more normative than descriptive, which, while not detracting from the scholarship, nonetheless makes his categories less useful for systematic evaluation purposes.

${ }^{103}$ For example, Nard cites K-2 Corp. v. Salomon S.A., 191 F.3d 1356 (Fed. Cir. 1999), as a clear example of the pragmatic/hypertextualist distinction. Nard, Claim Interpretation, supra note 10, at 61. In a passage quoted by Nard, Judge Rader in dissent suggested that the majority failed to ascertain the correct meaning of the phrase "permanently affixed" because it declined to return the case to the district court for factfinding on the meaning of "permanently" within the in-line skate art. K-2 Corp., 191 F.3d at 1370 (Rader, J., dissenting). Yet the majority opinion also engaged in what Nard describes as "pragmatic" reasoning: (1) neither party suggested at any time that the word "permanently" had a special meaning in this technological context (and, thus, the word was presumed to be given its common definition); and (2) in the context of the current dispute (the accused device had a removable screw where the patent claim called for a "permanent" affixation), the accused device clearly fell outside any reasonable contextual interpretation of "permanently." Id. at 1356. Thus, it seems difficult to discern the line Nard seeks to draw, except to the extent that the distinction is one simply of the degree of "pragmatism" involved (though one is left wondering what is "pragmatic" about requiring extensive expert testimony and evidentiary inquiries into the meaning of a commonly understood, nontechnical word).

${ }_{104}$ Romary \& Michelsohn, supra note 15, at 1887.

${ }^{105} I d$. at 1892.

${ }^{106}$ Id. at $1897-1917$. 
the specification to inform claim terms ${ }^{107}$ - both of which are clearly described by the methodological dichotomy we develop below.

\section{2. "Bottom Up" Measurement Design}

Ultimately, the opinions themselves inspired the design of this study's measurement criteria. A reading of a broad sample of the relevant dataset revealed a distinction between claim construction methodologies on the basis of the hierarchical status given to the sources of meaning of claim terms. Throughout the relevant time period, the Federal Circuit observably struggled with the tension inherent in two generally accepted (and conventionally cited) "canons" of claim construction: (1) that claim language is read in light of the specification of which it is a part; and (2) that the meaning of claim language may not be altered by importing or reading-in changes from outside the claims. Taken together, these canons recognize that the claim construction exercise is necessarily a contextual one, and they also attempt to preserve the function of the claim as the ultimate statement of patent scope. And yet the canons' inherent tension cannot be easily set aside: at what point does an appropriately contextual analysis spill over into impermissible importation of meaning into the claims? It is the resolution of this tension-which fundamentally exists in all disputes about the meaning of claim language ${ }^{108}$ - that provides the measurement criteria by which the Federal Circuit's methodological approach may be evaluated.

Two distinct approaches to resolving this tension were identified and defined. One line of reasoning, designated procedural, reveals a fairly formal process for analyzing the meaning of disputed claim terms, one that principally traverses according to a hierarchy of status among the various sources of meaning. The procedural approach starts with a general presumption in favor of the ordinarily understood meaning of claim language, typically drawn from a relevant -often technical-dictionary, reference works, or common usage. It then follows a predetermined path of analysis, wherein any suggested alteration from the ordinary meaning must be accompanied by

${ }^{107}$ Id. at 1917-26.

${ }^{108}$ In any dispute over claim language, one party or the other will almost invariably be arguing for more weight to be added to the "contextual" information, or at least will present competing information that necessarily requires the court to determine the weight it should be given. 
significant proof that such an alteration is required under the circumstances.

The alternative methodology, designated holistic, adopts a distinctly more free-form approach, seeking the correct meaning according to the particular circumstances presented, rather than following the formal steps and hierarchy of information sources seen in the procedural method. The holistic approach is significantly more relaxed than the procedural method in moving away from the abstracted "ordinary meaning" of a term in favor of a more localized understanding.

An example of the court's expression of the procedural approach is Johnson Worldwide Associates v. Zebco Corp.: ${ }^{110}$

We begin, as with all claim interpretation analyses, with the language of the claims. The general rule is, of course, that terms in the claim are to be given their ordinary and accustomed meaning. General descriptive terms will ordinarily be given their full meaning; modifiers will not

${ }^{109}$ In order to avoid potential confusion (or perhaps ideological baggage), these labels intentionally do not directly correspond with the well-known formalist (or "textualist") and pragmatist schools of interpretive method, though the methodological distinction drawn here obviously invokes at least aspects of that debate. See Daniel A. Farber, The Inevitability of Practical Reason: Statutes, Formalism, and the Rule of Law, 45 VAND. L. REV. 533, 548-49 (1992) (arguing that the real competing "issue" between formalists' and pragmatics' interpretive schemes is "the utility of a strong literalism presumption"); see also WILliam N. ESKRIDGE, JR., DyNAMIC STATUTORY INTERPRETATION 50-57 (1994) (discussing the pragmatist approach); RICHARD A. POSNER, OvERCOMING LAW 4-21 (1995) (same); Frank H. Easterbrook, The Role of Original Intent in Statutory Construction, 11 HARV. J.L. \& PUB. POL'Y 59, 59-66 (1988) (discussing the textualist/formalist approach); John F. Manning, Textualism as a Nondelegation Doctrine, 97 Colum. L. REV. 673, 674-75 (1997) (same); Antonin Scalia, Common-Law Courts in a Civil-Law System: The Role of United States Federal Courts in Interpreting the Constitution and Laws, in A MATTER OF INTERPRETATION: FEDERAL COURTS AND THE LAW 3, 23-29 (Amy Gutmann ed., 1997) (same). To be sure, both claim construction methodologies described here acknowledge and consult essentially the same sources of meaning, including what pragmatists call "contextual" information. See, e.g., Nard, Claim Interpretation, supra note 10, at 43-52 (discussing pragmatic approaches to claim interpretation); see also Richard A. Posner, The Problems of Jurisprudence 296 (1990) (noting the necessity of contextual information in discerning meaning); Stanley Fish, Almost Pragmatism: Richard Posner's Jurisprudence, 57 U. CHI. L. REv. 1447, 1456 (1990) (same). The critical difference here is in the process (or absence thereof) by which such information is used, with the "procedural" methodology ascribing to a significantly more rigid hierarchy in classifying the status of competing information. This distinction, which is based more on the structure and import of information than its consideration, seems to comport with at least some views of the textualist interpretive approach. See, e.g., Manning, supra, at 696 ("Not even the most committed textualist would claim that ... texts are inherently 'plain on their face,' or that all interpretation takes place within the four corners of the Statutes at Large.").

${ }^{110} 175$ F.3d 985 (Fed. Cir. 1999). 
be added to broad terms standing alone. In short, a court must presume that the terms in the claim mean what they say, and, unless otherwise compelled, give full effect to the ordinary and accustomed meaning of claim terms.

In order to overcome this heavy presumption in favor of the ordinary meaning of claim language, .... there must be a textual reference in the actual language of the claim with which to associate a proffered claim construction.

Our case law demonstrates two situations where a sufficient reason exists to require the entry of a definition of a claim term other than its ordinary and accustomed meaning. The first arises if the patentee has chosen to be his or her own lexicographer by clearly setting forth an explicit definition for a claim term. The second is where the term or terms chosen by the patentee so deprive the claim of clarity that there is no means by which the scope of the claim may be ascertained from the language used. In these two circumstances, a term or terms used in the claim invites-or indeed, requires-reference to intrinsic, or in some cases, extrinsic, evidence to determine the scope of the claim language.

By contrast, consider the discussion of methodology in Wang Laboratories, Inc. v. America Online, Inc.: ${ }^{112}$

The parties agreed before the district court that the term "frame" can in general usage be applied to bit-mapped display systems as well as to character-based systems; experts for both sides so testified. The disagreement was as to whether the term "frame" in the '669 claims embraced this general usage, or whether the term would be understood by persons of skill in this field as limited to the character-based systems described in the '669 patent. The district court started its analysis with the specification.

${ }^{111} I d$. at 989-90 (citations omitted); see also Renishaw PLC v. Marposs Societa' per Azioni, 158 F.3d 1243, 1248 (Fed. Cir. 1998) ("[T] he resulting claim interpretation must ... accord with the words chosen by the patentee ...."); Comark Communications, Inc. v. Harris Corp., 156 F.3d 1182, 1187 (Fed. Cir. 1998) ("In this case, the [disputed term] has a clear and well-defined meaning. This term is not so amorphous that one of skill in the art can only reconcile the claim language with the inventor's disclosure by recourse to the specification."); Va. Panel Corp. v. MAC Panel Co., 133 F.3d 860, 865-66 (Fed. Cir. 1997) (concluding that intrinsic evidence does not require modification of the ordinary meaning of "reciprocating"); York Prods., Inc. v. Cent. Tractor Farm \& Family Ctr., 99 F.3d 1568, 1572 (Fed. Cir. 1996) ("Without an express intent to impart a novel meaning to claim terms, an inventor's claim terms take on their ordinary meaning."); Bell Communications Research, Inc. v. Vitalink Communications Corp., 55 F.3d 615, 621-22 (Fed. Cir. 1995) (determining that the unmodified term "associating" is not limited to explicit association); Specialty Composites v. Cabot Corp., 845 F.2d 981, 987 (Fed. Cir. 1988) (holding that the unmodified term "plasticizer" is given the full range of ordinary and accustomed meaning).

${ }^{112} 197$ F.3d 1377 (Fed. Cir. 1999). 
The only system that is described and enabled in the '669 specification and drawings uses a character-based protocol. The specification mentions non-character-based protocols, [but $]$.... [t] he district court viewed the references to bit-mapped protocols as acknowledgments of the state of the art, and not as an enlargement of the invention described in the patent. We agree, and conclude that the references to other known protocols do not describe them as included in the applicant's invention, and that the specification would not be so understood by a person skilled in the field of the invention.

Wang states that the character-based protocol is simply a "preferred embodiment," and that the embodiment described in the specification does not set the boundaries of the claims .... Although precedent offers assorted quotations in support of differing conclusions concerning the scope of the specification, these cases must be viewed in the factual context in which they arose. Whether an invention is fairly claimed more broadly than the "preferred embodiment" in the specification is a question specific to the content of the specification, the context in which the embodiment is described, the prosecution history, and if appropriate the prior art, for claims should be construed, when feasible, to sustain their validity. The usage "preferred" does not of itself broaden the claims beyond their support in the specification. The only embodiment described in the '669 patent specification is the character-based protocol, and the claims were correctly interpreted as limited thereto. ${ }^{113}$

It is this contrast between the procedural and the holistic methodological approaches that forms the basis of our measurement criteria.

\section{Developing the Coding Instrument}

Once the measurement criteria were identified, a detailed coding instrument was developed. Initial review of a sample of the opinion set suggested that, while the basic methodological dichotomy was virtually certain to be present in each relevant case, many examples

${ }^{113} I d$. at 1381-83 (citations omitted). Note that, essentially by definition, the holistic methodological approach is more difficult to clearly discern from the cases. See also Cultor Corp. v. A.E. Staley Mfg., 224 F.3d 1328, 1331 (Fed. Cir. 2000) ("Whether a claim must, in any particular case, be limited to the specific embodiment presented in the specification, depends in each case on the specificity of the description of the invention ...."); Toro Co. v. White Consol. Indus., 199 F.3d 1295, 1301 (Fed. Cir. 1999) ("The specification does not describe an invention broader than [the] description of the cover and the restriction ring 'automatically' inserted and removed together."); O.I. Corp. v. Tekmar Co., 115 F.3d 1576, 1581 (Fed. Cir. 1997) ("All of the 'passage' structures contemplated by the written description are ... either non-smooth or conical."). 
(and, more to the point, expressions) of either approach would likely be found along a spectrum extending between strictly procedural and strictly holistic. Accordingly, in order to capture as much information as possible, the coding instrument allowed scoring of opinions in three categories of each methodology, representing strong, intermediate, and weak forms of the analysis. Thus, the coding scheme can be depicted graphically as in Figure 1 below.

Figure 1: A Taxonomy of Methodological Approach

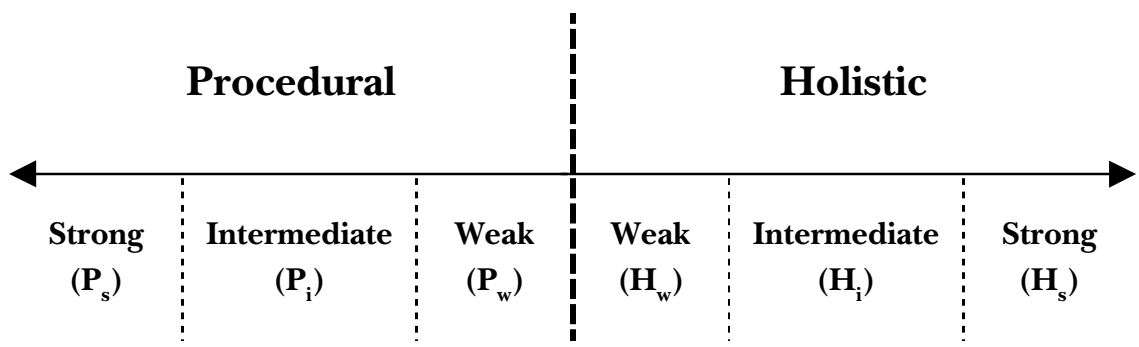

A textual description of the various subcategories is in Table 1: 
Table 1: A Taxonomy of Methodological Approach

\begin{tabular}{|c|c|c|c|c|c|c|}
\hline $\begin{array}{l}\text { Binomial } \\
\text { Categories }\end{array}$ & \multicolumn{3}{|c|}{ Procedural } & \multicolumn{3}{|c|}{ Holistic } \\
\hline $\begin{array}{l}\text { Detailed } \\
\text { Categories }\end{array}$ & $\begin{array}{c}\text { Strong } \\
\left(\mathrm{P}_{\mathrm{s}}\right)\end{array}$ & $\begin{array}{l}\text { Intermediate } \\
\qquad\left(\mathrm{P}_{\mathrm{i}}\right)\end{array}$ & $\begin{array}{l}\text { Weak } \\
\left(\mathrm{P}_{\mathrm{w}}\right)\end{array}$ & $\begin{array}{l}\text { Weak } \\
\left(\mathrm{H}_{\mathrm{w}}\right)\end{array}$ & $\begin{array}{l}\text { Intermedi- } \\
\text { ate }\left(\mathrm{H}_{\mathrm{i}}\right)\end{array}$ & $\begin{array}{c}\text { Strong } \\
\left(\mathrm{H}_{\mathrm{s}}\right)\end{array}$ \\
\hline $\begin{array}{l}\text { Textual } \\
\text { Description } \\
\& \\
\text { Coding } \\
\text { Instrument }\end{array}$ & $\begin{array}{l}\text { Expresses } \\
\text { rigid } \\
\text { process. } \\
\text { Ordinary } \\
\text { meaning } \\
\text { controls, } \\
\text { absent } \\
\text { express } \\
\text { definitions, } \\
\text { etc. }\end{array}$ & $\begin{array}{l}\begin{array}{l}\text { Framework of } \\
\text { formal process } \\
\text { established. }\end{array} \\
\text { Departure } \\
\text { along some } \\
\text { dimension: } \\
\text { no talk of } \\
\text { presumption, } \\
\text { extensive } \\
\text { discussion of } \\
\text { specification. }\end{array}$ & $\begin{array}{l}\text { Difficult to } \\
\text { discern the } \\
\text { form of } \\
\text { analysis. } \\
\text { Some } \\
\text { discussion/ } \\
\text { hint of } \\
\text { process. }\end{array}$ & $\begin{array}{l}\text { Difficult to } \\
\text { discern the } \\
\text { form of } \\
\text { analysis. } \\
\text { Little or no } \\
\text { discussion } \\
\text { of process } \\
\text { or ordinary } \\
\text { meaning. }\end{array}$ & $\begin{array}{l}\text { Acknow- } \\
\text { ledgement of } \\
\text { process, but } \\
\text { not used. } \\
\text { Specification } \\
\text { and/or } \\
\text { prosecution } \\
\text { history is } \\
\text { clearly } \\
\text { dispositive. }\end{array}$ & $\begin{array}{l}\text { No discussion } \\
\text { of process. } \\
\text { Immediate } \\
\text { use of } \\
\text { specification } \\
\text { or prosecu- } \\
\text { tion history. }\end{array}$ \\
\hline \multirow{3}{*}{$\begin{array}{l}\text { Example } \\
\text { Cases }\end{array}$} & $\begin{array}{l}\text { Johnson } \\
\text { Worldwide } \\
\text { Assocs. v. } \\
\text { Zebco } \\
\text { Corp., } 175 \\
\text { F.3d 985 } \\
\text { (Fed. Cir. } \\
\text { 1999) }\end{array}$ & $\begin{array}{l}\text { Insituform } \\
\text { Techs. v. Cat } \\
\text { Contracting, } \\
\text { Inc., 99 F.3d } \\
1098 \text { (Fed. } \\
\text { Cir. 1996) }\end{array}$ & $\begin{array}{l}\text { Ethicon } \\
\text { Endo- } \\
\text { Surgery v. } \\
\text { U.S. Surgical } \\
\text { Corp., } 93 \\
\text { F.3d } 1572 \\
\text { (Fed. Cir. } \\
\text { 1996) }\end{array}$ & $\begin{array}{l}\text { Litton Sys. } \\
\text { v. Honey- } \\
\text { well, Inc., } \\
87 \text { F.3d } \\
1559 \text { (Fed. } \\
\text { Cir. 1996) }\end{array}$ & $\begin{array}{l}\text { Harris Corp. } \\
\text { v. IXYS Corp., } \\
114 \text { F.3d } 1149 \\
\text { (Fed. Cir. } \\
\text { 1997) }\end{array}$ & $\begin{array}{l}\text { O.I. Corp. v. } \\
\text { Tekmar Co., } \\
115 \text { F.3d } \\
1576 \text { (Fed. } \\
\text { Cir. 1997) }\end{array}$ \\
\hline & $\begin{array}{l}\text { Neomagic } \\
\text { Corp. v. } \\
\text { Trident } \\
\text { Microsys. } \\
\text { Inc., 287 } \\
\text { F.3d } 1062 \\
\text { (Fed. Cir. } \\
\text { 2002) }\end{array}$ & $\begin{array}{l}\text { Micro Chem., } \\
\text { Inc. v. Great } \\
\text { Plains Chem. } \\
\text { Co., } 194 \text { F.3d } \\
1250 \text { (Fed. } \\
\text { Cir. 1999) }\end{array}$ & $\begin{array}{l}\text { Key Pharms. } \\
\text { v. Hercon } \\
\text { Lab. Corp., } \\
161 \text { F.3d } \\
709 \text { (Fed. } \\
\text { Cir. 1998) }\end{array}$ & $\begin{array}{l}\text { DSC Com- } \\
\text { muns. Corp. } \\
\text { v. Pulse } \\
\text { Communs., } \\
\text { Inc., } 170 \\
\text { F.3d 1354 } \\
\text { (Fed. Cir. } \\
\text { 1999) }\end{array}$ & $\begin{array}{l}\text { Aqua-Aerobic } \\
\text { Sys. v. Aera- } \\
\text { tors Inc., } 211 \\
\text { F.3d } 1241 \\
\text { (Fed. Cir. } \\
\text { 2000) }\end{array}$ & $\begin{array}{l}\text { Wang Labs., } \\
\text { Inc. v. Am. } \\
\text { Online, } \\
\text { Inc., } 197 \\
\text { F.3d } 1377 \\
\text { (Fed. Cir. } \\
\text { 1999) }\end{array}$ \\
\hline & $\begin{array}{l}\text { CCS Fitness, } \\
\text { Inc. v. } \\
\text { Brunswick } \\
\text { Corp., } 288 \\
\text { F.3d 1359 } \\
\text { (Fed. Cir. } \\
\text { 2002) }\end{array}$ & $\begin{array}{l}\text { 3M v. Chem- } \\
\text { que, Inc., } 303 \\
\text { F.3d } 1294 \\
\text { (Fed. Cir. } \\
\text { 2002) }\end{array}$ & $\begin{array}{l}\text { Brassica } \\
\text { Prot. Prods. } \\
\text { LLC v. } \\
\text { Sunrise } \\
\text { Farms, } 301 \\
\text { F.3d 1343 } \\
\text { (Fed. Cir. } \\
\text { 2002) }\end{array}$ & $\begin{array}{l}\text { Viskase } \\
\text { Corp. v. } \\
\text { Am. Nat'l } \\
\text { Can Co., } \\
261 \text { F.3d } \\
1316 \text { (Fed. } \\
\text { Cir. 2001) }\end{array}$ & $\begin{array}{l}\text { Smith \& } \\
\text { Nephew, Inc. } \\
\text { v. Ethicon, } \\
\text { Inc., 276 F.3d } \\
1304 \text { (Fed. } \\
\text { Cir. 2001) }\end{array}$ & $\begin{array}{l}\text { Cultor } \\
\text { Corp. v. A.E. } \\
\text { Staley Mfg., } \\
224 \text { F.3d } \\
1328 \text { (Fed. } \\
\text { Cir. 2000) }\end{array}$ \\
\hline
\end{tabular}

The coding instrument contains detailed definitions of each category. These definitions were revised several times based on feedback from coders and data concerning intracoder differences. After revision, the previously coded decisions were reconsidered in light of the altered instrument. In general, the instrument became increasingly detailed and precise upon each revision, thereby promoting the 
general objective of reducing, as much as possible, the subjectivity of coding determinations. ${ }^{114}$

\section{Evaluating the Measurement-Criteria I: Reliability}

As Lee Epstein and Gary King explain, there are two important measures of the quality of any selected measurement criteria: reliability and validity. ${ }^{115}$ Reliability refers to the property of the measurements as replicable and consistent, while validity refers to the extent to which the underlying concept is actually being captured by the measurement criteria. Here, given the direct correspondence between the objects of the study (quantification of methodological distinctions in Federal Circuit claim construction cases), validity is not really in question. ${ }^{116}$ Thus, the important evaluation is reliability.

As previously noted, we took care in developing the coding instrument to reduce, as much as possible, the subjectivity of coding decisions- that is, to try to avoid coding according to general "judgment calls" or "impressions." This practice is, of course, not only likely to increase the accuracy of the coding, but is calculated to make the study replicable or extensible by other researchers.

That being said, it must be acknowledged that the business of coding according to an expressed methodological approach-no matter the steps taken to wring as much subjectivity from the process as possible-is quite difficult. Furthermore, the coders in this study ${ }^{117}$ were both attorneys with technological backgrounds, admissions to the patent bar, and significant exposure to Federal Circuit doctrine. Whether our measurements could be successfully replicated by coders with different experiences is an open question. It is quite possible that, given the technologically complex and often intensely factual nature of many Federal Circuit opinions, this sort of study may actually require a skill set that precludes most law students (or even nonpatent lawyers) from being coders. While this is clearly an undesirable feature of the study, it may simply be inherent in the nature of the approach chosen.

In order to further evaluate and confirm the reliability of the measurements collected, each case in the dataset was independently coded by two coders. Discrepancies in coding were tallied, and the

${ }^{114}$ See infra Part II.D (describing the authors' coding methodology and process).

${ }_{115}$ Epstein \& King, supra note 97, at 82.

${ }_{116}$ See supra Part II.E (discussing the validity of the measurement criteria).

${ }^{117}$ Both authors coded all the opinions. 
coding differences were resolved by additional review of the opinions. Initial intercoder agreement was $92 \%$ on the basis of binomial categorizations (i.e., not considering the subcategories) and $72 \%$ across all categories. ${ }^{118}$

There seems to be relatively little attention paid in the literature to the "appropriate" level of intercoder agreement for studies of this type ${ }^{119}$ thus, confident conclusions are difficult to draw from this information. Intuition suggests, however, that the rate of intercoder agreement here (especially on the binomial measurement) is relatively high given the nature of the study. This might indicate a robust reliability for the measurement criteria and the coding instrument, though any such conclusions must be tempered by a recognition that the coders here were perhaps particularly appropriate for this task. ${ }^{120}$ Note again that the differences in coding results revealed by these evaluations were eventually rectified: those cases were recoded according to an agreement between the coders.

\section{E. Evaluating the Measurement-Criteria II: Validity}

In order to ensure that the study directly measures the information we seek-insight into the performance of the Federal Circuit in building its jurisprudence-the analytic method has been designed to closely reflect the results of the actual cases. ${ }^{121}$ That is, the methodological split identified and quantified here is directly linked to the outcomes of patent cases, thus allowing for meaningful conclusions to be drawn from the analysis. ${ }^{122}$ The relevance of the procedural/

${ }^{118}$ Because all intercoder differences were eventually resolved, the final intercoder agreement was $100 \%$. Initial agreement was tracked to provide information about the reliability of the data measurement system and to provide incremental feedback to the coders and authors concerning the coding instrument. Infra notes 144-49 and accompanying text.

${ }^{119}$ Epstein \& King noted that their United States Court of Appeals database reported a $95.2 \%$ intercoder agreement rate and that while this "seems high," it precludes detection of differences of less than 5\%. Epstein \& King, supra note 97, at 87 n.272; see also Sisk et al., supra note 82, at 1434-35 (noting that the authors had "few" disagreements on coding, all of which were ultimately resolved).

${ }^{120}$ Supra note 117 and accompanying text.

${ }^{121}$ Epstein and King refer to this as measurement reliability. See Epstein \& King, supra note 97 , at 83 (defining reliability as "the extent to which it is possible to replicate a measurement, reproducing the same value... on the same standard for the same subject at the same time").

${ }^{122}$ Put another way, if we were instead observing an interesting but ultimately irrelevant (as to actual results) distinction within the jurisprudence, then few meaningful conclusions could be drawn about the patterns we identify. 
holistic dichotomy is supported by the following line of reasoning. First, there is little doubt that claim construction generally, and the methodological approach to claim construction specifically, is crucially important to patent disputes. Second, the procedural/holistic categorization scheme is deeply tied to the patent jurisprudence itself, having been developed from the "bottom up" to reflect the issues and arguments that characterize this area of the patent law. Third, quantitative analysis of the jurisprudence fully supports the view that the methodology matters. We conclude that disputes concerning claim construction found in the jurisprudence itself mostly relate to disputes concerning methodological approach.

\section{Methodology as a Driver of Claim Construction}

The first issue will come as little surprise to students of patent law jurisprudence: the methodological approach to claim construction matters a great deal and is often determinative of the results of a claim construction analysis. By extension, this approach typically is dispositive of the outcome of a patent dispute. ${ }^{123}$ Thus, anything that systematically affects claim construction analysis will have a direct effect on both the actual interpretation of patent claims as well as the legal status of the patent at issue. The methodological approach, by establishing the framework by which claim construction analyses are conducted, is therefore crucial to determining the outcome.

It is important, however, to understand that the choice of methodological approach does not necessarily predict typical generalized descriptions of claim interpretation results. For example, even a strongly procedural approach will yield interpretations that can be described as both "broad" and "narrow." We note two cases evincing the same methodological approach (strong procedural). ${ }^{124}$ In Johnson Worldwide Associates v. Zebco Corp., ${ }^{125}$ the court issued a broad interpretation of the term "coupled" that encompassed both mechanical and electrical attachments. ${ }^{126}$ K-2 v. Salomon S.A., ${ }^{127}$ however, offered a "narrow" claim construction: the phrase "permanently affixed" was

${ }^{123}$ See, e.g., Markman I, 52 F.3d 967, 989 (Fed. Cir. 1995) (Mayer, J., concurring) ("All these pages and all these words cannot camouflage what the court well knows: to decide what the claims mean is nearly always to decide the case.").

${ }^{124}$ The cases were issued less than five months apart and were joined by two common judges-including their author, Judge Clevenger.

${ }^{125} 175$ F.3d 985 (Fed. Cir. 1999).

${ }^{126} I d$. at 992.

127191 F.3d 1356 (Fed. Cir. 1999). 
found to exclude attachment mechanisms such as screws. ${ }^{128}$ More generally, the methodological approach bears an even less predictable relationship to descriptions such as "infringed" or "invalid." This is because the results of a claim construction in any particular case do not predictably relate to the ultimate results of the dispute: while a "broader" claim interpretation might imply a broader scope of coverage-and thus a greater chance of finding infringement-it also increases the chance that the claim will be found invalid.

Notwithstanding the fact that the procedural/holistic dichotomy does not map precisely onto a broad/narrow distinction, our intuition is that the choice of a procedural methodological approach will, over the long run, yield generally more predictable (and perhaps broader) claim constructions than would the holistic approach. Greater predictability is, we believe, obvious: definitionally, the procedural approach, with its emphasis on the ordinary meaning of claim language as well as on the requirement for specified (and generally limited) reasons for straying beyond ordinary meaning, allows for far more certainty concerning the results of claim constructions than the holistic approach. ${ }^{129}$ That the procedural methodology will yield broader interpretations rests on more subtle arguments concerning the nature of these approaches. In particular, the holistic approach, by offering substantially greater flexibility, allows more opportunities for judges to tailor claim construction analyses according to other critical issues in the case, such as infringement or validity. The intuition, widely held in the patent law community, is that the influence of such exogenous factors will tend toward narrower claim constructions to avoid findings of either infringement or invalidity.

However, even if one does not share these intuitions concerning the long-run effects of each methodological approach, there can be little doubt that, for any particular case, the choice of methodological approach is likely to be a fundamental driver of the claim construction and, correspondingly, of the case outcome.

\section{The Reality of the Procedural/Holistic Dichotomy}

The second reason we believe the procedural/holistic dichotomy is linked to results is that this construct was drawn from the cases

128 Id. at $1363-65$.

129 As we describe more fully in Part III.C.1, infra, we also find a statistically significant relationship between variance in claim construction analysis and the incidence of the holistic methodological approach. 
themselves, as described in subsection II.B.2. That is, the categories were discovered rather than created - they are a fundamental feature of patent case law. To be sure, in order to ensure robust measurement techniques, the categories were formally named, characterized, and compartmentalized as part of this project; one will search in vain for any mention of a "holistic methodological approach" in Federal Circuit jurisprudence. Despite differences in nomenclature, however, the procedural/holistic dichotomy describes, we suggest, the basic terms of the claim construction debate at the Federal Circuit and beyond. ${ }^{130}$ The court itself seems to recognize this, with citation patterns neatly reflecting the methodological divide. Since April 1999, approximately one-third of opinions in our dataset coded as "strong procedural" $\left(\mathrm{P}_{\mathrm{s}}\right)$ rely in whole or in part on Johnson Worldwide for authority; leading opinions during the same timeframe exhibiting a "strong holistic" $\left(\mathrm{H}_{\mathrm{s}}\right)$ methodology take great pains to distinguish themselves from and/or reconcile themselves with Johnson Worldwide. ${ }^{131}$ Thus, the "bottom up" development of the procedural/holistic categorical framework has ensured that the distinction is closely tied to the jurisprudence. ${ }^{132}$

\section{Testing the Procedural/Holistic Categories}

A final, important assurance that the procedural/holistic categorization reflects real results in the cases comes from the data itself. In short, we found that disputes over claim construction outcomes found in the jurisprudence are overwhelmingly the result of disagreements concerning methodological approach and are fully captured by our measurement process. That is, when judges (whether of the Federal Circuit or district court variety) disagree about claim construction,

${ }^{130}$ See, e.g., Romary \& Michelsohn, supra note 15, at 1933.

${ }^{131}$ The Johnson Worldwide decision was issued in April 1999. 175 F.3d at 985. Our dataset contains 113 opinions since Johnson Worldwide that have been coded $\mathrm{P}_{\mathrm{s}}$. Shepard's ${ }^{\circledR}$ reports that at least twenty-nine of these opinions explicitly rely on Johnson Worldwide. Shepard's, at http://www.lexisnexis.com/shepards (last visited Jan. 30, 2004).

Major opinions invoking a strong holistic methodology (coded $\mathrm{H}_{\mathrm{s}}$ ) and distinguishing themselves from Johnson Worldwide include Bell Atlantic Network Services, Inc. v. Covad Communications Group, Inc., 262 F.3d 1258, 1273 (Fed. Cir. 2001), and SciMed Life Systems v. Advanced Cardiovascular Systems, Inc., 242 F.3d 1337, 1344 (Fed. Cir. 2001).

${ }^{132}$ In addition, this distinction can be viewed as a variation of both the traditional "rules versus standards" debate and the contest between the textualist and pragmatist schools of documentary interpretation. An animating assumption of the rich literature in each of these areas is that the methodological distinction has crucial, real-world importance. See supra note 109 and accompanying text. 
they do so on the basis of differing methodological approaches (in our terms, the procedural/holistic categorization scheme).

This conclusion was reached by two separate analytic methods. In the first, "alternative" opinions in the dataset were identified, together with their corresponding "majority" opinion. (For our purposes, an "alternative" opinion is defined as a concurrence or dissent that expresses a distinct claim construction outcome-e.g., a different meaning of a disputed term; a "majority" opinion is the opinion of the court.) ${ }^{133}$ We find that our coding categories tracked this dispute $95 \%$ of the time (19 of 20) using the detailed categories, or $65 \%$ of the time (13 of 20) according to binomial categories. That is, $95 \%(65 \%$ under the far less detailed binomial categorization) of disputes between Federal Circuit judges over claim construction found in the jurisprudence were the result of the differing methodological approaches described by our measurement scheme. We view this to be powerful evidence that the methodological approach to claim construction matters: it appears to be the genesis of almost all disputes. ${ }^{134}$

The second analysis involved district court decisions that were partially or fully reversed and remanded by the Federal Circuit on the basis of claim construction, where the Federal Circuit's construction was coded either "strong" or "intermediate" for either category, procedural or holistic $\left(\mathrm{P}_{\mathrm{s}}, \mathrm{H}_{\mathrm{s}}, \mathrm{P}_{\mathrm{i}}, \mathrm{H}_{\mathrm{i}}\right){ }^{135}$ Coding the corresponding district court decisions (where easily available) showed that over $82 \%$ of these erroneous decisions-i.e., those reversed or vacated by the Federal Circuit-were found so on the basis of a different methodological approach, according to the binomial procedural/holistic dichotomy. ${ }^{136}$ A related, broader examination of Federal Circuit opinions discussing

${ }^{133}$ Alternative opinions not directed to claim construction issues were omitted from the dataset. The dataset contained twenty alternative opinions; about $5 \%$ of cases decided had an alternative opinion.

${ }^{134}$ The single case where an alternative opinion exists with the same methodological approach as the majority opinion is Optimal Recreation Solutions, LLP v. Leading Edge Technologies, Inc., No. 00-1339, 2001 U.S. App. LEXIS 5772 (Fed. Cir. Apr. 6, 2001). A review of the dueling opinions in that case (both were coded as $\mathrm{P}_{\mathrm{s}}$ ) makes clear that the crux of the dispute was over the proper ordinary meaning of a claim term: specifically, whether the terms "memory" and "display" evoke structural characteristics.

${ }^{135}$ Federal Circuit opinions coded as "weak" $\left(\mathrm{P}_{w}, \mathrm{H}_{\mathrm{w}}\right)$ were omitted because of the difficulty in determining whether the Federal Circuit changed (or intended to change) the district court's claim construction analysis.

${ }^{136}$ The analysis here reviewed thirty-five available district court opinions (published in LEXIS databases). Of these, only twenty-two contained clear claim construction analyses, and in five of these, the Federal Circuit affirmed the claim construction. Fourteen of the seventeen remaining opinions were reversed on the basis of a change (according to binomial categories) in methodological approach. 
in some detail the corresponding district court's claim construction revealed that in at least $75 \%$ of the cases reversed, the reversal was based on the difference in methodological approach, again using binomial categories. ${ }^{137}$

Both analyses-disagreements concerning claim construction within the Federal Circuit and disagreements between the Federal Circuit and the district courts-strongly support the view that the methodological approach to claim construction, in particular the methodological categorization system developed here, matters a great deal.

\section{F. Data Collection and Measurement}

\section{Selection of Judicial Opinions}

The potential population of judicial decisions included all written Federal Circuit opinions decided from April 23, 1996 through November 1, 2002. The first date is when Markman II was decided by the Supreme Court, and was thus chosen definitionally. ${ }^{138}$ The latter date was chosen arbitrarily.

This potential population was reduced according to the selection criteria, which was that the opinion had to offer an observable patent claim construction analysis, because without the ability to consider the court's expressed analytic approach, there was nothing to measure. This selection was achieved in a two-step process. The first was an electronic database search strategy, which involved repetitively searching the relevant LEXIS $^{139}$ and Westlaw ${ }^{140}$ judicial databases using

${ }^{137}$ Thirty-nine Federal Circuit cases were analyzed, and twenty-nine appeared to have reversed the district court on the basis of methodological approach (binomial categories). Of the remaining ten, most simply did not provide enough information to discern what analytical fault existed in claim construction, and two were reversed for claim construction reasons unrelated to methodology (construing the wrong term, and selecting the wrong "means" in an analysis based on the "means plus function" format authorized by 35 U.S.C. $\S 112$, para. 6 (2000)).

${ }^{138}$ See supra Part I.B (explaining the significance of Markman II).

139 The LEXIS database used is designated "Federal Circuit-US Court of Appeals Cases" or "CAFC." Coverage includes all published and unpublished opinions from October 1982 to the present, and the file is updated daily. See LEXIS, at http:// www.lexis.com (last visited Jan. 30, 2004).

${ }^{140}$ The major Westlaw database used is designated "U.S. Court of Appeals for the Federal Circuit Cases" or "CTAF." Coverage includes "reported and unreported documents" from October 1982 to the present. The update schedule is not specified. See Westlaw, at http:/ /www.westlaw.com (last visited Jan. 30, 2004). 
methods and terms calculated to capture all possible opinions that fell within the selection criteria. ${ }^{141}$ Most (if not all) of these opinions appeared on multiple results lists; all results were combined and repetitive records deleted. In addition, clearly inapplicable records were deleted at this phase (e.g., case titles of the form "[Party] v. [Secretary of Veterans Affairs]"). After this stage of the selection process, the population of cases numbered over 750. Cases that, upon examination, did not meet the population criteria were set aside. ${ }^{142}$ The total number of opinions in the dataset is $413 .{ }^{143}$

In addition, the "United States Patent Quarterly" or "USPQ" database, also located in Westlaw, was used for some searches. Id.

${ }^{141}$ For example, the collection strategies included the following:

1. In the LEXIS "Federal Circuit-US Court of Appeals Cases" database: ("claim construction" or (claim /2 construction) or "claim interpretation" or (claim /3 interpretation) or (interpretation /3 claim)).

2. In the Westlaw "United States Patent Quarterly" database: classification codes 125.1305, 125.1303, or 120.03 restricted to the Federal Circuit and the period April 23, 1996 to November 1, 2002.

3. The Markman I and II decisions were "Shepardized" (a LEXIS function) for citation in the Federal Circuit during the relevant time period.

${ }^{142}$ Note that opinions containing claim construction analysis in the context of appeals brought from the PTO Board of Patent Appeals and Interferences were not included in the population. This is because the claim construction scheme for unissued patents is distinct (at least as a doctrinal matter) from that of issued patents and involves largely distinct precedent and criteria. Specifically, the PTO is expected to give proposed claims their "broadest reasonable construction," purportedly to ensure the broad applicability of the prior art. See, e.g., In re Graves, 69 F.3d 1147, 1152 (Fed. Cir. 1995) (upholding the PTO's broad reading of a claim); In re Etter, 756 F.2d 852, 858 (Fed. Cir. 1985) (en banc) (affirming the appropriate standard as giving claims their "broadest reasonable interpretation"). While there is at least some question whether the "broadest reasonable" metric might be de facto comparable to the framework established by the Federal Circuit when reviewing district court decisions, see Duffy, supra note 10, at 127 (downplaying any distinction), the reasoning and relevant precedents are sufficiently distinct so as to make these opinions inappropriate for inclusion in this study population. The authors estimate that the total number of opinions affected by this exclusion was under twenty.

A significant number of claim construction analyses involving 35 U.S.C. § 112, para. 6 (2000) were excluded for similar reasons: the identification of structure in the specification that "corresponds" to claim function is clearly a distinct inquiry. On the other hand, an interpretation of the claimed function in a $\S 112$, para. 6 claim element is a traditional claim construction inquiry and opinions addressing these issues were included in the dataset.

${ }^{143}$ Concurrences and dissents were included in the dataset as separate observations if they otherwise complied with the selection criteria. Overall analyses of the court's jurisprudence omitted these records; the dataset included 393 opinions for the court. 


\section{Coding Judicial Opinions}

As previously noted, each opinion in the initial dataset was independently coded by two readers according to the expressed methodological approach of the opinion. ${ }^{144}$ The readers' coding included the subcategories; the binomial coding was taken directly from the subcategory score. ${ }^{145}$ Each opinion that contained an observable claim construction analysis was individually coded; thus, dissents, concurrences, and other nonmajority opinions were treated as separate observations when they met the criteria of observable claim construction analysis. ${ }^{146}$

The methodological coding scores were entered directly into spreadsheet software packages by the readers to avoid data entry errors. In addition to the coding scores, the following information was collected for each opinion in the dataset: ${ }^{147}$

- Case name/title/parties

- Federal Circuit docket number

- Date issued

- Disposition of appeal

- Citation(s) ${ }^{148}$

- Type of opinion (sole/majority/alternate)

- Panel judges (names)

- Judges joining the opinion (names)

- Authoring judge (names) ${ }^{149}$

The data was collected and analyzed using off-the-shelf statistical and database software. ${ }^{150}$

${ }^{144}$ While each opinion is obviously unique, the readers estimated that the coding process took, on average, approximately ten to fifteen minutes per opinion.

${ }^{145}$ Again, "binomial" refers to whether the opinion expressed a holistic or procedural methodological approach, irrespective of the strength of the form. That is, to determine the binomial coding scores, the subcategories were collapsed: opinions coded as containing strong, intermediate, or weak forms of the holistic methodology are all coded holistic in the binomial measurement scheme. See supra Part II.C (explaining the classification scheme).

${ }^{146}$ Separate opinions on non-claim construction topics were ignored.

147 Again, in an effort to minimize data entry problems and to avoid the need for manual proofreading of the entire dataset, this information was collected solely electronically, using specially written software scripts to collect and allocate the data from standard electronic LEXIS and Westlaw files.

${ }^{148}$ The LEXIS citation was collected for all opinions. Where available, the Federal Reporter citation was collected as well.

${ }^{149}$ Opinions without a signing judge were coded "per curiam" for the author.

${ }^{150}$ Microsoft Excel 2002 for Mac OS X was the primary data management tool; 


\section{STUDY RESULTS}

Analysis of the collected data is split into three general categories. The first looks at the observed methodological approach evinced by the court as a whole during the period of the study. The second evaluates whether there are any discernible trends over time. The third considers the observed methodological approach of the individual judges on the Federal Circuit to determine whether opinion authorship or panel membership is related to expressed methodology.

\section{A. Overall Results ${ }^{151}$}

Table 2 describes the overall frequency distribution of the Federal Circuit's claim construction methodologies since Markman II, where the methodological approach is expressed in binomial form-that is, where the strong/intermediate/weak categories are collapsed.

Table 2: Frequency of Methodologies (binomial, $n=393$ )

\begin{tabular}{|l|l|l|}
\cline { 2 - 2 } & procedural & holistic \\
\hline $\mathrm{n}$ & 248 & 145 \\
\hline$\%$ & $63.1 \%$ & $36.9 \%$ \\
\hline
\end{tabular}

Table 2 suggests that the procedural methodology is predominant, though perhaps not overwhelmingly. ${ }^{152}$

Figure 2 breaks out the categorical details, with the score for each methodological approach indicated as a percentage of the observations (court: $n=393$, alternative: $n=20$ ) and as a numeric total. Figure 2 includes the profile of the alternative opinions for comparison purposes.

statistical analyses were conducted with the assistance of SPSS 11.0 (2002). Graphing was done in Excel.

${ }^{151}$ Unless otherwise specified, the results in the following Section reflect opinions written for the court only; alternative opinions (dissents, concurrences) in the dataset were otherwise omitted.

${ }^{152}$ Overall observations (including alternative opinions) had the following profile $(n=413)$ :

\begin{tabular}{|c|c|c|}
\hline & procedural & holistic \\
\hline$n$ & 259 & 154 \\
\hline$\%$ & $62.7 \%$ & $37.3 \%$ \\
\hline
\end{tabular}


Figure 2: Frequency Distribution of Methodologies (Categorical)

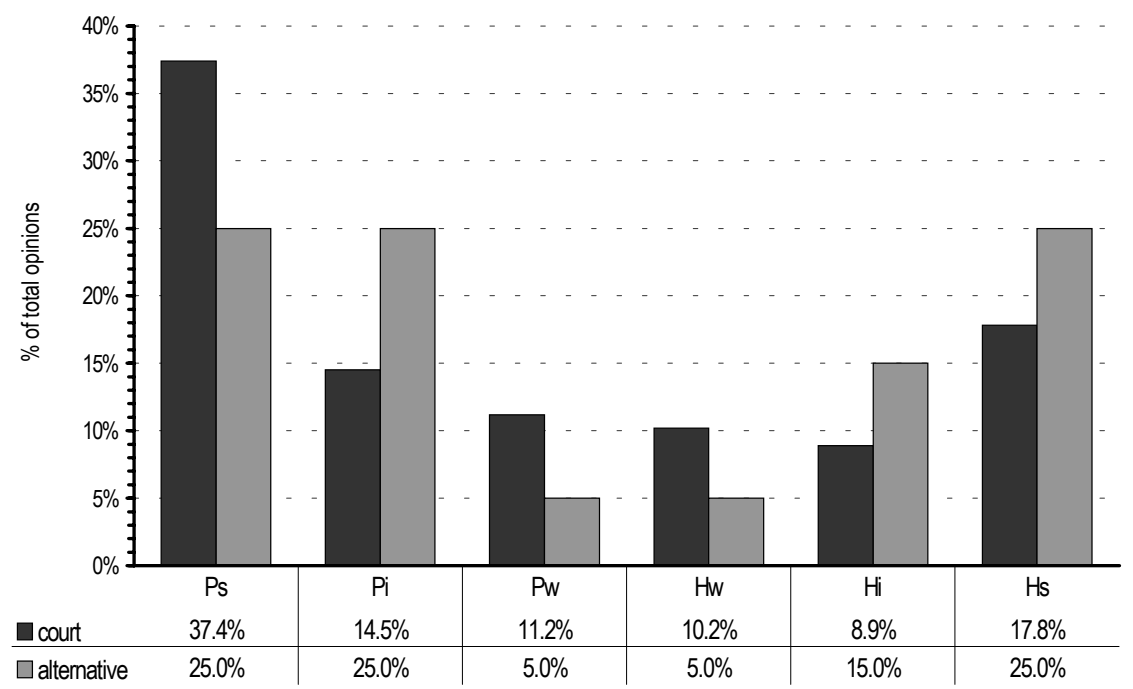

The strong form of the procedural methodology was observed more than twice as often as any other methodological approach, followed by the strong form of holistic, and then the intermediate form of procedural. The general shape of the histogram (ordered according to the taxonomy noted in Figure 1) suggests that the court's methodological approach tends to be somewhat polar, favoring stronger expressions of methodology.

\section{B. Methodological Trends over Time}

The time period for this study spanned about six-and-a-half years, from April 1996 to November 2002. Accordingly, it was possible to evaluate the court's methodological approach over time and to consider whether any trends might be discernible.

Because opinions are not issued by the Federal Circuit at a uniform rate, utilizing calendar-related criteria to separate the series of opinions resulted in widely varying groups of opinions. To offset this problem, the dataset was separated into twenty-two bins in chronological order, with each bin representing approximately two to four 
months during the period of the study. Each bin contains eighteen or nineteen opinions. ${ }^{153}$

\section{Overall Trends}

Figure 3 shows the methodology (binomial categorization) over time, expressed in terms of the percentage of holistic observations.

Figure 3: Methodology over Time (Binomial)

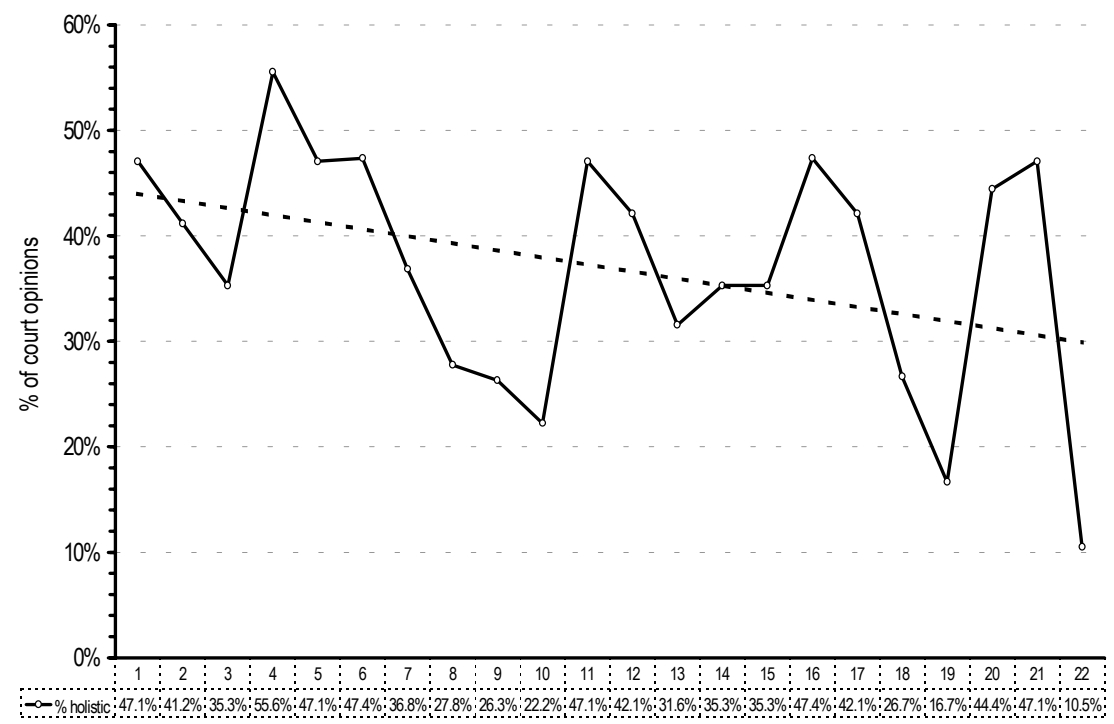

The downward-sloping trend line superimposed on the graph indicates that the frequency of the holistic methodological approach (when categorized in binomial form) tended to decrease during the period of the study. ${ }^{154}$

In an effort to produce a clearer picture of the real trends at the Federal Circuit, Figure 4 digs somewhat deeper into the data by

${ }^{153}$ Bin selection and separation was done on the basis of the overall dataset, including alternative opinions. Considering opinions for the court alone, bin size varies from sixteen to nineteen.

${ }^{154}$ The trend line was calculated according to the ordinary least squares (OLS) procedure. The slope of the trend line $(m)$ is $-0.672 \%$. The square of Pearson's product moment (or coefficient of correlation $r^{2}$ ) is 0.144 , indicating some (though relatively weak) correlation between the period and percentage of holistic observations. The t-value $(t)$ for the slope is 1.84 , which indicates that the slope is statistically significant at the $95 \%$ level $(p \leq .05)$. 
depicting the frequency trends of both strong and weak methodological approaches (irrespective of whether such approaches were procedural or holistic) during the period of the study.

Figure 4: Proportion of Strong/Weak Approaches over Time

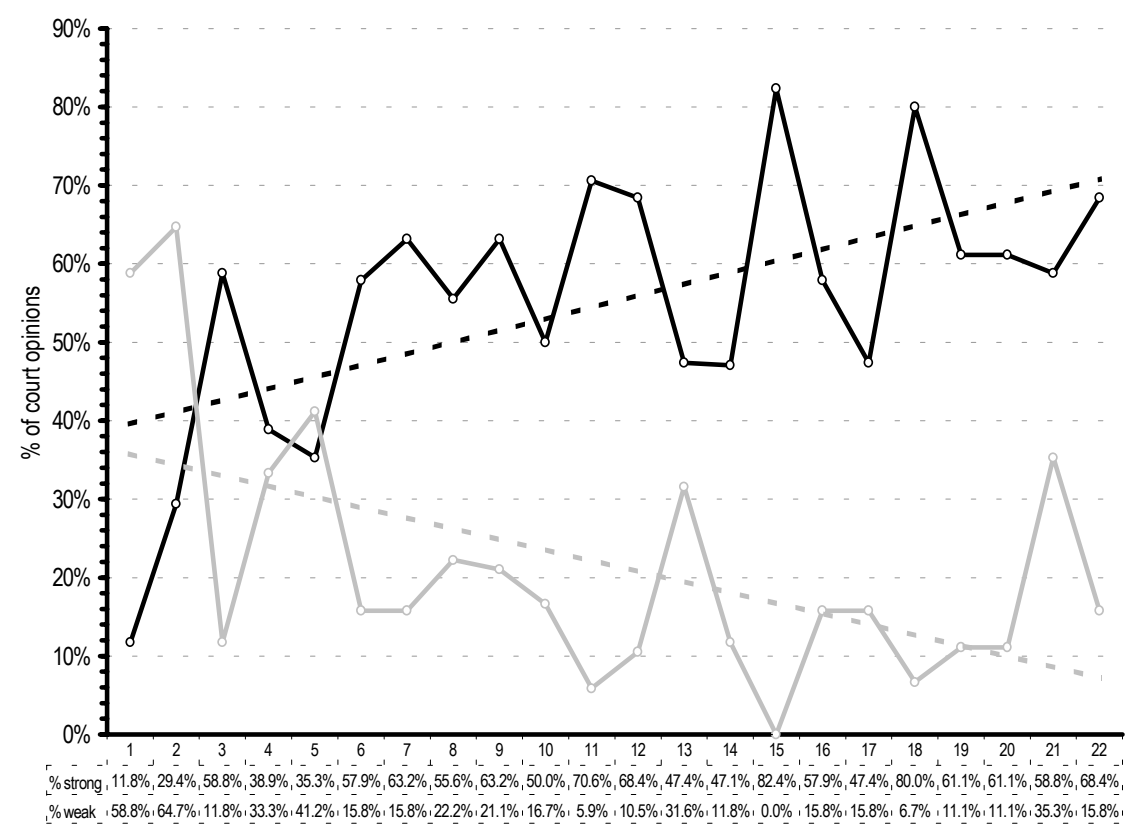

Again, trend lines were superimposed on the graph. ${ }^{155}$ The striking result here is the marked increase in the "extremism" of the Federal Circuit during the period of the study: moving from near parity between strong and weak forms of methodological approach in early periods to a jurisprudence increasingly characterized by strong forms of analysis. Note that one byproduct of this increasing extremism is likely to be an increasing reversal rate over time because lower courts may be unable to determine the proper approach and/or the Federal Circuit may become less forgiving of alternative methodologies. This observation is supported by Chu's results showing an increasing rate of claim construction changes over time. ${ }^{156}$

${ }^{155}$ Both trend lines are reasonably correlated and statistically significant. For the \% strong data: $m=1.488 \%, r^{2}=0.350, t=3.218, p \leq .005$. For the $\%$ holistic data: $m=-1.360 \%, r^{2}=0.286, t=2.833, p \leq 0.01$.

${ }^{156} \mathrm{Chu}$ found that there was a statistically significant increase in the rate that the Federal Circuit changed claim constructions over time. Chu, supra note 10, at 1102. 


\section{Authorship Activity Patterns}

The significant rise in methodological extremism revealed by Figure 4 suggested further analysis of the data. Using the statistical profiles developed for each judge, ${ }^{157}$ the trends in Figures 3 and 4 were deconstructed by analyzing changes in Federal Circuit judicial activity. First, two groups of judges were identified according to their statistical profile as Proceduralists (i.e., those most likely to author opinions stating a procedural methodological approach) or Holistics (i.e., those most likely to author opinions stating a holistic methodological approach). ${ }^{158}$ The percentage of Federal Circuit opinions authored by each group was calculated for each period in the study. The authorship activity trend for the Proceduralists was found to be strongly positive and statistically significant. ${ }^{159}$ Figure 5 depicts this result.

\section{Figure 5: Trends of Opinion Authorship Activity}

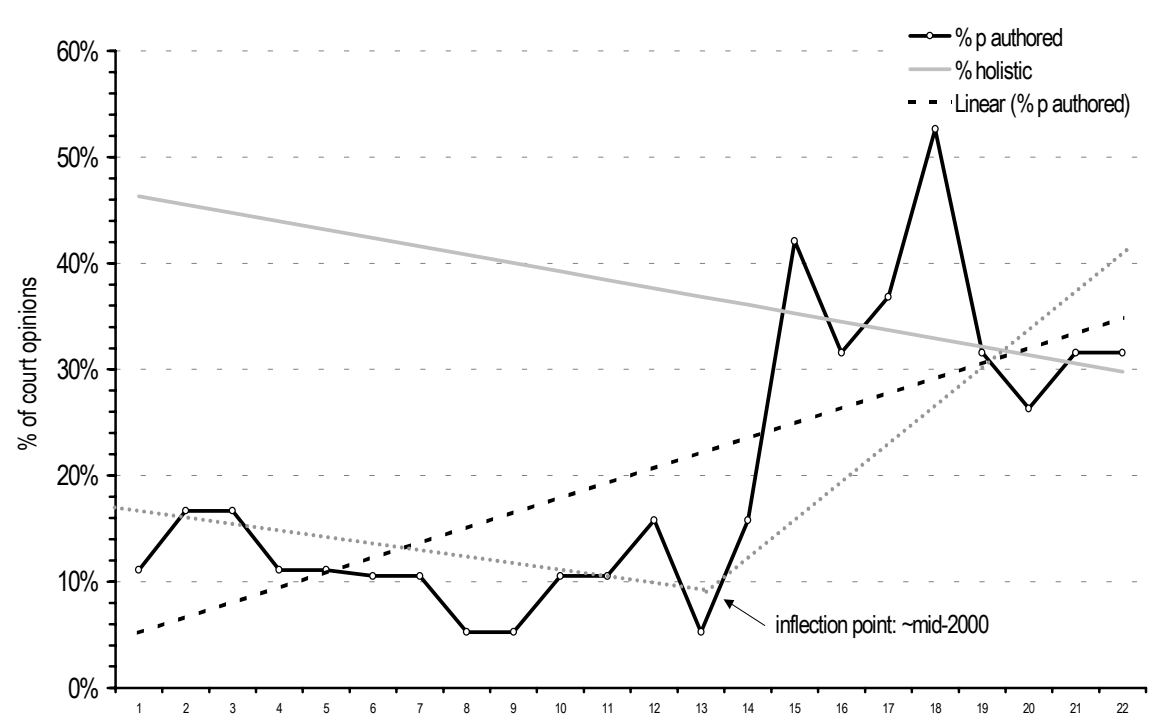

Note, however, that Chu's population covered only a twenty-eight-month subset of this study. Id. at 1092.

${ }^{157}$ See infra Part III.C (describing the statistical profiles of each Federal Circuit judge's claim construction decisions).

${ }^{158}$ Proceduralists are those whose standardized M-index (a constructed measure of overall methodological approach) score places them outside one standard deviation below the mean score; Holistics are those whose standardized M-index score places them outside one standard deviation above the mean score. See infra notes 170-74 and accompanying text for a detailed discussion of the M-index and grouping assignments. 
The downward-sloping line (\% holistic) is the court's overall trend line taken from Figure 3. The trend line for Proceduralist author activity $(\%$ authored $)$ is relatively well-correlated and statistically significant. $^{160}$

Figure 5 reveals a major part of the answer posed by Figure 3: the Federal Circuit's claim construction jurisprudence becomes more procedural over time in large part because of the increasing authorship activity of the Proceduralist judges. A major factor in this increase in activity has been changes in judicial personnel: of the three judges defined as Proceduralists, only one was on the court throughout the period of the study; the remaining two joined the court after January 1, 2000. ${ }^{161}$ The superimposed trendlines for the first and second half of the study reveal a sharp inflection point around mid2000, which is when Judges Linn and Dyk (two of the three Proceduralists) began hearing cases.

While Figure 5 explains the decreasing incidence of the holistic methodological approach at the Federal Circuit, it does not offer much insight into the increasing extremism of the Federal Circuit depicted in Figure 4. Figure 6, however, depicts the authorship trends of a group of judges that fit within a definition of "strong" authorsthose whose opinions were coded as evincing a strong methodological approach (irrespective of whether procedural or holistic) and fall within the top quartile of this statistic for all judges.

${ }^{159}$ For $\%$ authored: $m=1.413 \%, r^{2}=0.477, t=4.259, p \leq 0.0001$. The authorship activity trend for the Holistic group (\% holistic) was found to be stable (slope $\approx 0$ ) but statistically insignificant.

${ }^{160}$ For $\%$ p authored: $m=1.548 \%, r^{2}=0.577, t=5.232, p \leq 0.0001$.

For $\%$ h authored: $m=-0.693 \%, r^{2}=0.135, t=1.769, p \leq 0.05$.

The Proceduralists

\begin{tabular}{|l|c|c|}
\hline \multicolumn{1}{|c|}{ Judge } & Years in Dataset & \# Opinions \\
\hline Clevenger & all & 48 \\
\hline Linn & 2000-end & 21 \\
\hline Dyk & 2000-end & 14 \\
\hline
\end{tabular}

The Holistics

\begin{tabular}{|l|c|c|}
\hline \multicolumn{1}{|c|}{ Judge } & Years in Dataset & \# Opinions \\
\hline Newman & all & 28 \\
\hline Lourie & all & 58 \\
\hline Bryson & all & 29 \\
\hline
\end{tabular}




\section{Figure 6: Opinion Authorship Activity of "Strong" Authors}

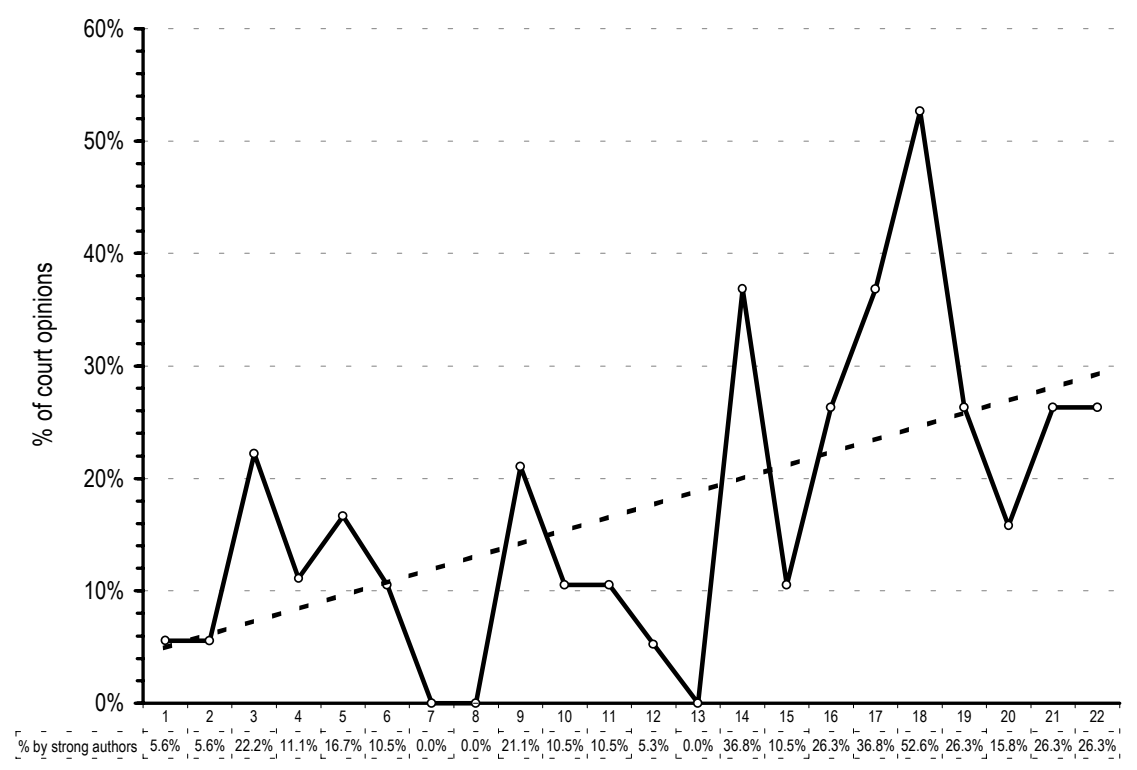

The trend line in Figure 6 suggests that the activity of "strong" authors on the Federal Circuit increased, perhaps by five-fold, during the period of the study. ${ }^{162}$ Again, a large part of this can be attributed to personnel changes: two of the five judges classified as "strong" authors joined the court after January $1,2000 .{ }^{163}$ Combined, they account for $45 \%$ of all "strong" opinions authored.

To briefly summarize, the results over time show the following key trends:

Trend 1: A gradual but significant shift in methodological approach to claim construction away from holistic, in favor

${ }^{162}$ For \% by "strong" authors: $m=1.162 \%, r^{2}=0.305, t=2.966, p \leq 0.05$.

163

"Strong" Authors

\begin{tabular}{|l|c|c|}
\hline Judge & Years in Dataset & \# Opinions \\
\hline Friedman & all & 1 \\
\hline Mayer & all & 8 \\
\hline Schall & all & 27 \\
\hline Linn & 2000-end & 21 \\
\hline Dyk & 2000-end & 14 \\
\hline
\end{tabular}


of the procedural approach (Figure 3).

Trend 2: A substantial increase in the extremism of the Federal Circuit's claim construction jurisprudence, measured by the frequency of "strong" methodological approaches (Figure 4).

In both cases, changes in court personnel seem to be at the core of the developments. Trend 1 is largely explained by the increasing activity of Proceduralist judges-a factor substantially driven by the addition of Judges Linn and Dyk to the court in 2000. Similarly, Trend 2 results in large part from the increasing authorship activity of judges with a propensity to write "strong" methodological opinions, a factor again influenced by the arrival of Judges Linn and Dyk.

From an institutional evaluation perspective, these results are mixed. While Trend 1 (Figure 3) demonstrates a movement towards proceduralism, it nonetheless makes clear that the holistic methodological approach remains a current (and apparently enduring) feature of the Federal Circuit's jurisprudence. This in turn suggests that the methodological split noted in Part IV.A is likely to remain for the foreseeable future, thereby reducing the predictability and stability of the jurisprudence and potentially keeping the district court reversal rate at relatively high levels.

Trend 2 (Figure 4) offers an arguably more positive view of the jurisprudential developments. Here, there are two plausible stories. The first is that the marked increase in extremism is evidence of an ongoing doctrinal struggle over claim construction at the Federal Circuit, where the addition of Proceduralist judges such as Linn and Dyk has spurred their Holistic brethren (Judges Bryson and Lourie) to adopt a more aggressive approach. This view is less compelling, however, when one considers the relatively low rate of disputes concerning claim construction that appear in the jurisprudence; the population contains only about a $5 \%$ rate of alternative claim construction opinions (as expressed in dissents or concurrences). ${ }^{164}$

Thus, the more plausible story related to Trend 2 is that the Federal Circuit is indeed responding to the Markman II mandate by increasingly focusing on-and developing-claim construction guidelines. Thus, the trend towards polarization is a byproduct of the clearer and sharper ways by which the court is analyzing claims (or, more precisely, expressing its analysis of them). While part of this

\footnotetext{
${ }^{164}$ Of the total opinion population of 413 , twenty opinions are alternative claim construction analyses.
} 
development seems to have been a move towards the procedural forms of analysis, the more significant observation may be that the court is attempting to fulfill the Markman II requirement of a coherent doctrine of claim construction. Under this view, the jurisprudence prior to Markman II may have been relatively less clear or evinced relatively weaker forms of analysis, and the important shift is the increase in stronger (and thus more clearly stated) methodological forms.

Whichever explanation one chooses-a struggle for supremacy over claim construction methodology or the expected result of doctrinal development-the trends generally support the view that the Federal Circuit is (1) increasingly focusing on the methodological approach to claim construction and (2) gradually moving to a more unified (procedural) methodological scheme. ${ }^{165}$ Both of these must be considered broadly positive developments, likely to move the Federal Circuit closer to its mandate of uniformity and predictability.

\section{The Methodology of Federal Circuit Judges}

This Section develops a detailed statistical profile of each Federal Circuit judge with respect to his or her expressed claim construction methodology. This information is useful in evaluating how different judges approach the task of the Federal Circuit, as well as in illustrating the internal debates and tensions on the court.

\section{Descriptive Data}

Table 3 presents basic descriptive data for each of the sixteen Federal Circuit judges included in the dataset, listed in order by number of opinions joined. ${ }^{166}$

${ }^{165}$ Note that these trends, of course, do not suggest that the reversal rate of district court opinions is likely to drop, thus confirming the results of Chu and Moore. See Chu, supra note 10, at 1102 (showing an increase in Federal Circuit reversals of district court claim construction decisions over a twenty-eight-month period since the beginning of 1998); Moore, supra note 14, at 11 (finding that the Federal Circuit reversed district court claim constructions in $33 \%$ of all appealed patent cases between Markman II and the end of 2000). As the Federal Circuit wrestles with its own jurisprudence, the district courts are likely to (a) have difficulty in discerning the appropriate mode of claim construction analysis and/or (b) face reversal because of the relatively fluid nature of the Federal Circuit's guidelines. Moving targets are difficult to hit, and the results here seem to suggest that the court is creating such a moving target with respect to claim construction methodology.

${ }^{166}$ A judge was considered to have joined an opinion if he or she either authored or joined the decision of the court without a concurrence or dissent. Authors of 
Table 3: Federal Gircuit Judges in Dataset

\begin{tabular}{|l|c|c|c|c|}
\hline \multicolumn{1}{|c|}{ Judge } & $\begin{array}{c}\text { Years in } \\
\text { Dataset }\end{array}$ & $\begin{array}{c}\text { Opinions } \\
\text { Joined }\end{array}$ & $\begin{array}{c}\text { Opinions } \\
\text { Authored }\end{array}$ & Alt. Rate \\
\hline Clevenger (RC) & all & 109 & 48 & $6.3 \%$ \\
\hline Rader (RR) & all & 106 & 48 & $6.3 \%$ \\
\hline Schall (AS) & all & 103 & 27 & $3.7 \%$ \\
\hline Lourie (AL) & all & 101 & 58 & $1.7 \%$ \\
\hline Newman (PN) & all & 100 & 28 & $7.1 \%$ \\
\hline Bryson (WB) & all & 97 & 29 & $3.4 \%$ \\
\hline Gajarsa (AG) & $1997-$ end & 92 & 31 & $3.2 \%$ \\
\hline Mayer (RM) & all & 90 & 8 & $50.0 \%$ \\
\hline Michel (PM) & all & 83 & 27 & $7.4 \%$ \\
\hline Plager (JP) ${ }^{\dagger}$ & all & 63 & 11 & $0.0 \%$ \\
\hline Rich (GR) ${ }^{\dagger+}$ & start-1999 & 51 & 18 & $0.0 \%$ \\
\hline Dyk (TD) & $2000-$ end & 40 & 14 & $0.0 \%$ \\
\hline Linn (RL) & $2000-$ end & 39 & 21 & $4.8 \%$ \\
\hline Archer (GA) ${ }^{\dagger}$ & all & 35 & 12 & $0.0 \%$ \\
\hline Friedman (DF) & all & 30 & 1 & $100.0 \%$ \\
\hline Prost (SP) & $2001-$ end & 8 & 3 & $0.0 \%$ \\
\hline per curiam & N/A & - & 29 & - \\
\hline
\end{tabular}

${ }^{\dagger}$ Inactive status as of June 2003.

${ }^{+\dagger}$ Died May 1999.

Note that twelve judges were on active status as of June 2003. The column labeled "Alt. Rate" indicates the proportion of alternative opinions authored by the judge as a percentage of total opinions authored. Among the twelve active judges, the average rate of alternative opinions is $7.8 \%$, with Judge Mayer appearing especially active on this front with a $50 \%$ rate. $^{167}$

alternative opinions (concurrences or dissents) were considered to have joined the alternative opinions.

${ }^{167}$ Note that Judge Mayer authored proportionally far fewer claim construction opinions than did his colleagues. 


\section{Judicial Methodology}

Next we turn to measurements of the judges' methodological approaches. To get an intuitive sense of the range of differences, Figure 7 displays the frequency of judges in the dataset to write (and join) opinions of either procedural or holistic methodology, expressed as a percentage of opinions coded as holistic. ${ }^{168}$ Judges are sorted in ascending order, with the lowest values (most procedural) to the left. ${ }^{169}$

Figure 7: The Methodology of Federal Circuit Judges (\% holistic)

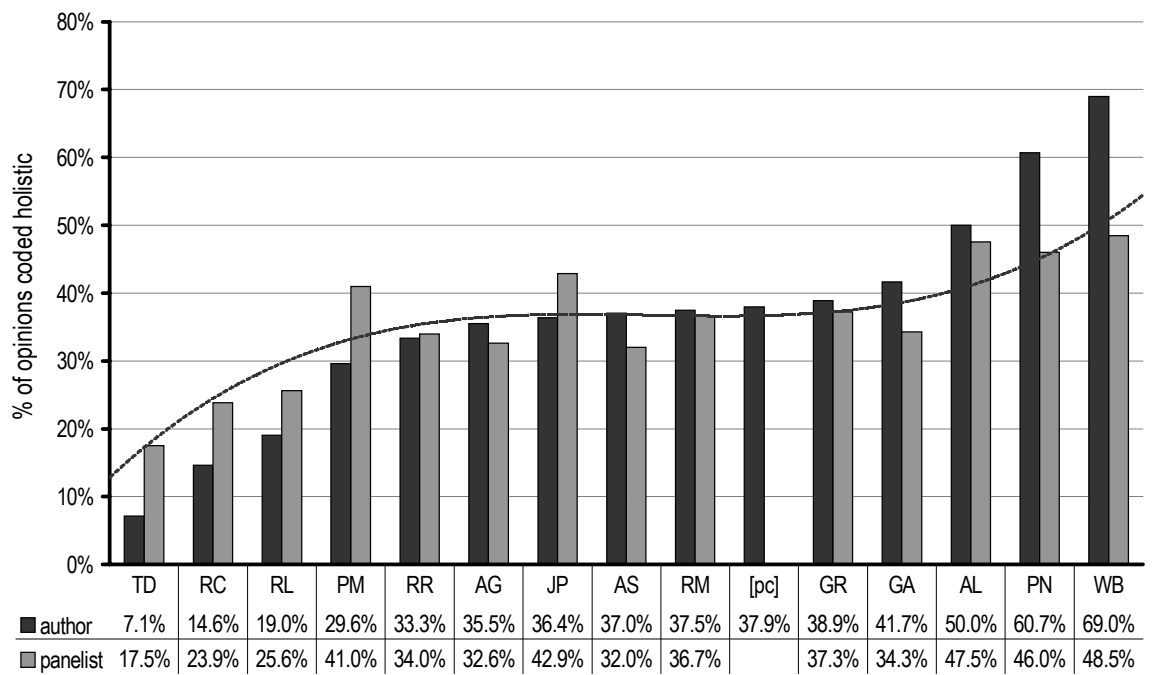

The overall mean percentage of holistic opinions is $38.1 \%$ for the author data, and $35.9 \%$ for the panelist data.

Note that, as intuition suggests, judges appear less "extreme" in the panelist data, with a total range of $31.0 \%$ (17.5\% to $48.5 \%)$ versus a total range of $61.9 \%(7.1 \%$ to $69.0 \%)$ for the author data. That is, judges appear to relax their preferences somewhat when joining opinions, and authors appear to enjoy a degree of latitude when describing the methodological approach in their own opinions. In addition, and perhaps more importantly, the distribution of the data (shown by

${ }^{168}$ Judges Friedman and Prost are not displayed in Figure 7 because their significantly smaller sample sizes obscured the overall results.

${ }^{169}$ Note that $[\mathrm{pc}]$ represents unsigned (per curiam) opinions. Obviously, there is no panelist data for $[\mathrm{pc}]$. 
the curved line superimposed on Figure 7, with steep slopes near each end and a flattened curve near the mean) suggests that the judges on the court can usefully be thought of as groups. The three to four judges at each end of the chart are markedly more extreme than the bulk nearer the middle, thereby creating three groups or factions.

\section{Factions on the Federal Circuit}

We next describe the groups or factions of the Federal Circuit identified in Figure 7. First, to more precisely evaluate the judges' methodological approaches, a calculated index (denoted M-index) was developed. ${ }^{170}$ The advantage of the M-index over the cruder binomial percentages of Figure 7 is that it captures (with a single number) the propensity of a judge to author or join opinions exhibiting a procedural or holistic methodological approach, as well as reflects the strength of reasoning utilized. It does this by weighting opinions according to strength of methodology, as well as measuring the general categorical form (procedural/holistic). M-index scores range from 0 to 1 , with a score of 1 indicating a perfectly strong holistic $\left(\mathrm{H}_{\mathrm{s}}\right)$ approach, and 0 indicating a perfectly strong procedural $\left(\mathrm{P}_{\mathrm{s}}\right)$ approach. $^{171}$

Table 4 reports the results of the $M$-index calculation, and groups the judges into one of three categories. ${ }^{172}$ Proceduralists are those whose standardized $M$-index score $^{173}$ places them outside one standard

${ }^{170}$ This index is loosely based on an index developed by Professors Segal and Cover for describing the political leanings of Supreme Court justices, based on categorical data (there, coded newspaper editorials describing the justices). Jeffrey A. Segal \& Albert D. Cover, Ideological Values and the Votes of U.S. Supreme Court Justices, 83 AM. POL. SCI. REV. 557, 559 (1989); see also King \& Epstein, supra note 97, at 82, $90-92$ (discussing the Segal/Cover index extensively).

${ }^{171}$ The equation used is:

$$
M-\text { index }=\left[\frac{1}{2}\right]\left[\frac{\left(n_{H_{S}}-n_{P_{S}}\right)+\frac{1}{2}\left(n_{H_{i}}-n_{P_{i}}\right)+\frac{1}{10}\left(n_{H_{w}}-n_{P_{w}}\right)}{n_{H_{S}}+n_{P_{S}}+n_{H_{i}}+n_{P_{i}}+n_{H_{w}}+n_{P_{w}}}+1\right]
$$

where $n_{x}$ represents the number of opinions attributable to that judge (i.e., either authored or joined) coded for a particular methodological approach. Note that intermediate and weak opinions are weighted $1 / 2$ and 1/10 of strong opinions, respectively, representing judgments about the relative impact of each form of methodological approach.

${ }^{172}$ Table 4 uses authorship data $(n=413)$. The reasoning is that the authorship data best represents the judges' true preferences and is thus most appropriate for interjudge comparisons.

${ }^{173}$ A standardized score refers to the difference between the raw score (here, the $M$-index) and the mean score, expressed in terms of standard deviations. That is, a 
deviation below the mean score; Holistics are those whose standardized M-index score places them outside one standard deviation above the mean score. ${ }^{174}$ The Swing Judges are those remaining.

Table 4: Categories of Federal Circuit Judges ${ }^{175}$

\begin{tabular}{|c|l|c|c|}
\cline { 2 - 4 } \multicolumn{1}{c|}{} & Judge & $\begin{array}{c}\text { M-index } \\
\text { (authors) }\end{array}$ & Std. Score \\
\hline \multirow{4}{*}{ Proceduralists } & Dyk & 0.121 & $(1.79)$ \\
\cline { 2 - 4 } & Clevenger & 0.199 & $(1.25)$ \\
\cline { 2 - 4 } & Linn & 0.202 & $(1.22)$ \\
\hline \multirow{5}{*}{ Swing Judges } & Rader & 0.334 & $(0.30)$ \\
\cline { 2 - 4 } & Michel & 0.335 & $(0.30)$ \\
\cline { 2 - 4 } & Mayer & 0.344 & $(0.24)$ \\
\cline { 2 - 4 } & [pc] & 0.367 & $(0.07)$ \\
\cline { 2 - 4 } & Gajarsa & 0.369 & $(0.06)$ \\
\cline { 2 - 4 } & Archer & 0.379 & 0.01 \\
\cline { 2 - 4 } & Plager & 0.386 & 0.06 \\
\cline { 2 - 4 } & Schall & 0.406 & 0.19 \\
\cline { 2 - 4 } & Rich & 0.428 & 0.35 \\
\hline \hline \multirow{5}{*}{ Holistics } & Lourie & 0.542 & 1.14 \\
\cline { 2 - 4 } & Bryson & 0.619 & 1.68 \\
\cline { 2 - 4 } & Newman & 0.636 & 1.80 \\
\hline
\end{tabular}

Table 4 sets forth a descriptive account of claim construction at the Federal Circuit: that the methodological approach of the court is split rather cleanly among three groups. As has been the case throughout the analysis, Table 4 highlights the importance of personnel changes at the Federal Circuit: two of the three most recent

standardized score of 1 describes a case where the individual $M$-index is one standard deviation above the mean score.

${ }^{174}$ The validity of this assignment criteria can be seen in the "Std. Score" column of Table 4: very significant gaps exist in the judges' distribution at those locations.

${ }^{175}$ Judges Friedman and Prost were not included in the grouping analysis because of very low sample sizes. 
additions to the court, Judges Linn and Dyk, are solid Proceduralists. ${ }^{176}$ All Proceduralists and Holistics are currently in active status.

This identification of the methodological camps within the Federal Circuit offers the opportunity to investigate the impact that these groups of judges have on the Federal Circuit's jurisprudence. ${ }^{177}$ One aspect of the analysis was discussed in Part IV.B: this grouping seems to explain many of the overall trends observed in this study.

\section{Judicial (In) consistency}

As a final judge-specific analysis, the methodological variance of the Federal Circuit judges was calculated. This result allows some comparative insight into the consistency (or lack thereof) of individual judges' methodological approaches to claim construction. Variance was calculated according to the standard deviation of each judge's authored opinions on a binomial basis. Thus, this statistic measured the propensity of a judge to vary between procedural and holistic methodologies. Table 5 reports this result, with the judges ordered from least variable (i.e., least likely to vary between methodological approaches) to most.

${ }^{176}$ Judge Prost, the most recent addition, was not included in the grouping analysis because of a small sample size: three authored opinions in the dataset. All of these opinions were procedural.

${ }^{177}$ Infra Part III.D. 
Table 5: Methodological Variance of Federal Circuit Judges

\begin{tabular}{|c|l|c|}
\hline Rank & Judge & Variance \\
\hline 1 & Dyk & 0.267 \\
\hline 2 & Clevenger & 0.357 \\
\hline 3 & Linn & 0.402 \\
\hline mean & & $\mathbf{0 . 4 6 3}$ \\
\hline 4 & Michel & 0.465 \\
\hline 5 & Bryson & 0.471 \\
\hline 6 & Rader & 0.476 \\
\hline 7 & Gajarsa & 0.486 \\
\hline 8 & Schall & 0.492 \\
\hline 9 & per curiam & 0.494 \\
\hline 10 & Newman & 0.497 \\
\hline 11 & Rich & 0.502 \\
\hline 12 & Lourie & 0.504 \\
\hline 13 & Plager & 0.505 \\
\hline 14 & Archer & 0.515 \\
\hline 15 & Mayer & 0.518 \\
\hline
\end{tabular}

The striking observation flowing from Table 5 is the separation between the least variable judges (Dyk, Clevenger, and Linn) and the relatively more clustered remainder. In other words, it appears that most Federal Circuit judges have relatively similar levels of inconsistency in claim construction methodology, but a small group is substantially more consistent. Further, this consistent group overlaps perfectly with the Proceduralist group identified in Table 4, suggesting (1) a relationship between methodological approach and consistency, ${ }^{178}$ and (2) the impact of the Proceduralists on the Federal Circuit's claim construction doctrine.

Table 5's implications for overall judicial performance are somewhat unclear-absent a well-defined baseline, it is difficult to know whether these scores are relatively consistent or inconsistent in the realm of methodological approaches. One thing does seem clear, however: it is possible for most Federal Circuit judges to substantially reduce their variability. Judges Dyk, Clevenger, and Linn seem to

${ }^{178}$ For a discussion of this relationship and its implications, see infra Part IV.A. 
have done a markedly better job on this front, and provide something of a roadmap for the rest of the court to follow.

\section{Predicting the Federal Circuit: Panel and Author Dependency in Claim Construction}

The final set of results explores the relationships between the Federal Circuit judges assigned to a case and the methodological approach to claim construction used for the analysis. ${ }^{179}$ We find, contrary to at least one judge's assertions, ${ }^{180}$ that the individual membership and overall composition of a three-judge panel that decides an appeal has a statistically significant effect on the methodological approach used to analyze claim construction issues. Indeed, in some cases, we can attach specific probabilities to this relationship at a $95 \%$ confidence level. In short, we find ample evidence of panel dependency in claim construction at the Federal Circuit. ${ }^{181}$

\section{Panel Membership and Methodology}

First, we find that the empanelling of many (though not all) Federal Circuit judges in our dataset has a statistically significant effect on the claim construction analysis. In the analysis that follows, we find that we can predict, with statistically significant confidence, the impact of the methodological approach of half (6 of 12) of the active judges of the Federal Circuit.

${ }^{179}$ At least one study has shown that the identity of the author of an opinion can influence the result. See John R. Allison \& Mark A. Lemley, How Federal Circuit Judges Vote in Patent Validity Cases, 27 FLA. ST. U. L. REV. 745, 757 (2000) (finding a strong correlation between the identity of the authoring judge and whether the decision upheld the validity of a patent). Other studies have found no such relationship. See, e.g., Chu, supra note 10, at 1115-19 (finding no significant relationship between rate of reversal and authorship).

${ }^{180}$ There has been fairly widespread criticism of the Federal Circuit among practitioners of patent law that the court's decisions and reasoning are highly dependent upon the composition of any individual panel and/or dependent upon the identity of the authoring judge. See, e.g., Paul R. Michel, The Court of Appeals for the Federal Circuit Must Evolve to Meet the Challenges Ahead, 48 AM. U. L. REV. 1177, 1191 (1999). Judge Michel's reply to this criticism was: "I believe that these complaints are exaggerated. By informal monitoring, I estimate that in ninety percent of the cases the result would be the same with any combination of three judges from among the court's present complement of ten judges in full-time service." Id.

${ }^{181}$ Note that, contrary to many observers, we do not necessarily conclude that panel dependency is undesirable. Indeed, by allowing an increase in the predictability of Federal Circuit decision making, it may be broadly beneficial. For a full discussion of the implications of panel dependency, see infra Parts IV.B.1-3. 
Binary logistic regression analysis was used to model the relationship between judicial identity and methodological approach (binomial categories). Logistic regression is particularly well-suited to this form of analysis, as it is highly effective at estimating the probability that an event will occur given certain parameters. The dependent variable of interest here is binary: whether an opinion exhibits a holistic $($ score $=1$ ) or procedural $($ score $=0$ ) methodological approach. Our independent variables are the identities of the judges. ${ }^{182}$ Table 6 shows the results of the regression on panel data, with statistically significant results highlighted.

${ }^{182}$ Panel composition data was recoded into a series of binary dummy variables $(0,1)$ indicating whether a particular judge joined or authored an opinion. 
Table 6: Panel Membership and Methodological Approach ${ }^{183}$

\begin{tabular}{|l|c|c|c|c|}
\hline \multicolumn{1}{|c|}{ Judge } & B & S.E. & $\operatorname{exp(B)}$ & $\begin{array}{c}\text { Holistic } \\
\text { Probability }\end{array}$ \\
\hline Dyk & -1.368 & $0.441^{* *}$ & 0.254 & $20.3 \%$ \\
\hline Clevenger & -1.020 & $0.250^{* *}$ & 0.361 & $26.5 \%$ \\
\hline Linn & -0.894 & $0.397 * *$ & 0.409 & $29.0 \%$ \\
\hline Prost & -0.674 & 0.865 & 0.509 & $33.7 \%$ \\
\hline Rader & -0.486 & $0.234^{* *}$ & 0.615 & $38.1 \%$ \\
\hline Schall & -0.446 & $0.237 *$ & 0.64 & $39.0 \%$ \\
\hline Gajarsa & -0.294 & 0.255 & 0.746 & $42.7 \%$ \\
\hline Rich & -0.281 & 0.319 & 0.755 & $43.0 \%$ \\
\hline Mayer & -0.166 & 0.244 & 0.847 & $45.9 \%$ \\
\hline Michel & -0.025 & 0.255 & 0.975 & $49.4 \%$ \\
\hline Newman & 0.157 & 0.228 & 1.171 & $53.9 \%$ \\
\hline Lourie & 0.365 & 0.229 & 1.441 & $59.0 \%$ \\
\hline Bryson & 0.589 & $0.234 * *$ & 1.801 & $64.3 \%$ \\
\hline
\end{tabular}

$*$ significance at .10

$* *$ significance at .05

${ }^{183}$ The regression was performed using binary logistic regression. The dependent variable was the methodology $(1,0)$, and the independent variables $(16)$ were dummy variables representing panel membership $(1,0)$ for all judges in the dataset. No constant was included in the model.

Summary statistics for the model are:

\begin{tabular}{|c|c|c|}
\hline -2 Log likelihood & $\begin{array}{c}\text { Cox \& Snell } \\
\text { R Square }\end{array}$ & $\begin{array}{c}\text { Nagelkerke } \\
\text { R Square }\end{array}$ \\
\hline 499.592 & 0.162 & 0.216 \\
\hline
\end{tabular}

Currently inactive judges are not displayed in Table 6 , though their data was included in the model. None of their coefficients were statistically significant. 
In Table 6, B represents the coefficient associated with the judge's membership on a panel: positive numbers indicate an increased probability of a holistic opinion. The column labeled S.E. reports the standard error for the coefficient; the level of significance of the coefficient B is indicated. For our purposes, values of less than 0.1 were deemed significant, indicating a greater than $90 \%$ likelihood that the coefficient is not attributable to chance. The $\exp (\mathrm{B})$ column is the odds-ratio of the coefficient, the change in odds that the event will occur (here, a holistic opinion) given a unit increase in the independent variable (here, the participation of the judge). Put more simply, the odds-ratio reports the change in odds that an opinion will be holistic as a result of the judge joining the opinion. Finally, the Holistic Probability column reports the probability (in percentage terms) of a holistic opinion, given the judge's participation. ${ }^{184}$ For example, Judge Bryson's participation implies a $64.3 \%$ chance of a holistic methodological approach, while Judge Dyk's participation suggests only a $20.3 \%$ chance.

\section{Dependency and Factions}

Next, we report the expressed claim construction methodology given the participation of Proceduralist or Holistic judges on the panel.

${ }^{184}$ Probability $=$ odds $/(1+$ odds $)$. 
Table 7: Proceduralists, Holistics, and Methodology

\begin{tabular}{|c|c|c|c|}
\hline & & \multicolumn{2}{|c|}{ Opinion Methodology } \\
\hline & & Procedural & Holistic \\
\hline \multirow{4}{*}{$\begin{array}{l}\text { Number of } \\
\text { Proceduralist } \\
\text { judges } \\
\text { empanelled }^{185}\end{array}$} & 0 & $\begin{array}{c}121 \\
(54.3 \%)\end{array}$ & $\begin{array}{c}102 \\
(45.7 \%)\end{array}$ \\
\hline & 1 & $\begin{array}{c}107 \\
(71.3 \%) \\
\end{array}$ & $\begin{array}{c}43 \\
(28.7 \%) \\
\end{array}$ \\
\hline & 2 & $\begin{array}{c}17 \\
(100.0 \%)\end{array}$ & - \\
\hline & 3 & - & - \\
\hline \multirow{4}{*}{$\begin{array}{l}\text { Number of } \\
\text { Holistic } \\
\text { judges } \\
\text { empanelled }^{186}\end{array}$} & 0 & $\begin{array}{c}114 \\
(78.1 \%)\end{array}$ & $\begin{array}{c}32 \\
(21.9 \%)\end{array}$ \\
\hline & 1 & $\begin{array}{c}107 \\
(54.3 \%)\end{array}$ & $\begin{array}{c}90 \\
(45.7 \%)\end{array}$ \\
\hline & 2 & $\begin{array}{c}24 \\
(53.3 \%)\end{array}$ & $\begin{array}{c}21 \\
(46.7 \%)\end{array}$ \\
\hline & 3 & - & $\begin{array}{c}2 \\
(100.0 \%) \\
\end{array}$ \\
\hline \multicolumn{2}{|l|}{ Overall Results } & $\begin{array}{c}245 \\
(62.8 \%)\end{array}$ & $\begin{array}{c}145 \\
(37.2 \%)\end{array}$ \\
\hline
\end{tabular}

Table 7 reports the contours of the relationship between the number of Proceduralist or Holistic judges empanelled in a given case and the methodological outcome. The data reveals that a greater participation of Proceduralist judges resulted in a greater frequency of a procedural approach to claim construction. Similarly, a greater participation of Holistic judges yielded a greater likelihood of a holistic approach. These relationships are statistically significant, meaning we can reject the hypothesis that they occurred by chance.

Even a cursory glance at the cell values in Table 7 suggests that the participation of Proceduralist judges is particularly important to the

${ }^{185}$ For this portion of the table, $\chi^{2}=21.712, \mathrm{df}=2, \mathrm{p} \leq 0.001$.

${ }^{186}$ For this portion of the table, $\chi^{2}=25.775, \mathrm{df}=3, \mathrm{p} \leq 0.001$. 
claim construction methodology. In all cases where Proceduralist judges comprised a majority of the three-judge panel (17 cases), the resulting opinion was procedural in nature; the procedural rate was $71.3 \%$ when only a single Proceduralist was on the panel (150 cases). In contrast, the Holistics appear to have a somewhat lesser effect, even when in the majority.

These results imply that parties appealing to the Federal Circuit can draw some statistically significant inferences about the outcome of a claim construction analysis given a known panel membership. ${ }^{187}$ Of course, an important limitation to any such inferential analysis is that the data here represent past judicial behavior patterns. For such information to be meaningful, one must assume that such patterns will continue into the future. This assumption may not hold: one might expect judges to alter their views or, perhaps, to write opinions more clearly. Indeed, a major goal of this Article is to encourage Federal Circuit judges to take the methodological approach to claim construction seriously. Thus, in a sense, if this Article succeeds, the results may actually diminish in real-world predictive value.

\section{Dependency, Factions, and Panels}

Of course, describing the results in terms of individual judges' membership on a panel potentially misses some of the richness and nuance that attends the interpersonal dynamics between the judges. Therefore, we developed a series of ten dummy panels, using the three-group categories (procedural, holistic, and swing) noted above. (Using each of the 220 real panels was impractical.) ${ }^{188}$ The dummy panels described a three-member panel in terms of the judicial factions: for example, procedural, procedural, and swing (denoted PPS). Figure 8 depicts the frequency with which these panels used each methodological approach.

\footnotetext{
${ }^{187}$ See infra Part IV.B for the policy implications of this result.

${ }^{188}$ Given a set of twelve active judges $(n)$, with three-judge panels $(k)$, the formula $x=\frac{n !}{k !(n-k) !}$ yields the possible combinations $(x)$.
} 
Figure 8: Frequency of Methodological Approach, Dummy Panels

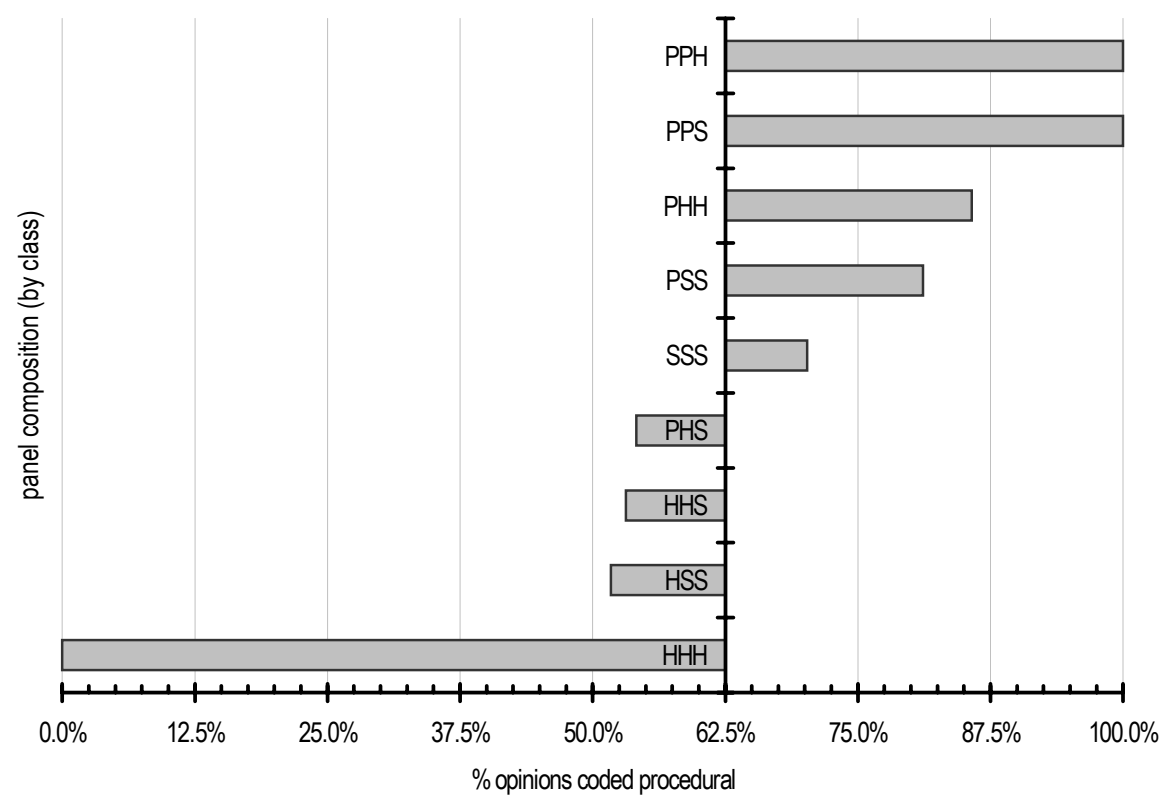

As expected, panels dominated by Proceduralist members are far more likely to evince a procedural approach than those dominated by Holistics.

\section{The Institutional Implications of Panel Dependency}

Subsections 1 and 2 demonstrate rather forcefully that Federal Circuit claim construction analysis is related in a statistically significant way to the composition of the panel of judges that hears and decides the case. To many observers, this will come as little surprise-as noted above, panel dependency is an oft-repeated criticism of the Federal Circuit. ${ }^{189}$

Note, however, that the institutional implications of panel dependency are not themselves necessarily troubling. Panel dependency implies some predictability in Federal Circuit behavior and predictability is, of course, both a generally positive development and a particular mandate for the Federal Circuit. In addition, many readers may review the results of subsections 1 and 2 and conclude that the

${ }^{189}$ See, e.g., Michel, supra note 180, at 1191 (describing the problem of panel dependency). 
judges identified with a particular theory of claim construction (Proceduralists, Holistics, etc.) are impeding the Federal Circuit's institutional mandate as the manager of patent law. This critique, however, is misplaced: those judges whom we find to have a predictable (at least within our dataset) effect on claim construction are benefiting the court, not harming it. Indeed, in our view, subsections 1 and 2 are something of an indictment of those judges whose statistical profile indicates no predictable effect on the approach to claim construction; it is these judges who seem to be major contributors to the perceived unpredictability of the Federal Circuit.

\section{SUCCESS AND THE FEDERAL CiRCUIT: THE IMPLiCATIONS AND SOME POLICY PRESCRIPTIONS}

The study presented above offers a number of important insights into both the institutional design of the U.S. Patent System and its implementation. The major findings include:

1. The Federal Circuit's claim construction jurisprudence evinces a distinct split in methodological approach, a dichotomy that both involves a significant number of decisions and appears to affect the results of the cases.

a. The Federal Circuit uses a procedural methodological approach in $63.1 \%$ of the cases in our dataset and a holistic methodological approach in the remaining $36.9 \%$.

b. "Strong" forms of each methodological approach are the most common observations in the dataset.

2. During the period of the study, the procedural methodological approach became more prevalent.

a. This trend appears to be driven in large part by a substantial increase in authorship activity among judges whose statistical profile indicates a strong preference for the procedural methodological approach (the Proceduralists).

b. The rise of Proceduralist activity appears strongly related to the addition of new judges to the Federal Circuit in 2000.

3. The Federal Circuit's claim construction jurisprudence became more polarized, with an increasing trend towards strong methodological approaches, and a decreasing trend towards weak approaches. 
a. This trend can be explained, in part, by an increase in activity among judges that frequently author "strong" opinions of either methodological approach.

4. The methodological approaches of individual judges on the Federal Circuit vary widely and can be usefully divided into three groups: the Proceduralists, the Holistics, and the Swing Judges.

5. Claim construction analysis at the Federal Circuit is clearly affected by the composition of the panel that hears and decides the case.

a. The participation (e.g., number of panel members) of both Proceduralists and Holistics affects the claim construction analysis, though in opposite ways.

b. One-half (6) of the currently active judges have statistically significant individual effects on claim construction.

In the Sections that follow, we briefly discuss the implications of these major findings, both in terms of the success of the Federal Circuit as an institution as well as the several policy recommendations that are suggested by the results.

\section{A. Is the Federal Circuit Succeeding?}

This study paints a decidedly mixed picture of the Federal Circuit. Certainly, aspects of the results here support the view that the court is not meeting its mandate for uniformity and predictability, especially in the wake of Markman II. The distinct and enduring split in methodological approach, a trend of increasing polarity, and the association between different claim construction analyses and the judges themselves all provide ammunition to critics of the Federal Circuit's performance. Other findings, however-the increasing dominance of the procedural approach to claim construction, the increasing importance of the most consistent judges, and the changes wrought by recent additions to the court-counsel against a one-dimensional view of the Federal Circuit as a court in crisis.

An important perspective of the Federal Circuit offered through the lens of this analysis is one of a court undergoing significant transition. There seem to be two parallel mechanisms at work. In the first, the court seems to be attempting to respond to the mandate of Markman II (and perhaps to the criticism of its early efforts). This can be seen in the "sharpening" of the expressed methodological approach in the jurisprudence, suggesting heightened awareness of the 
importance of analytic method and perhaps a related debate concerning the appropriate methodological approach. Moreover, a response to Markman II might also be driving the trend of increasing proceduralism, representing the court's gradual coalescence towards a common methodological approach. Such a "response" mechanism, which implies a change in Federal Circuit jurisprudence, is consistent with the sense that the doctrine is somewhat unstable, leading to relatively high rates of reversal.

The second transformative mechanism at work in the Federal Circuit is even less subtle: the findings of this study repeatedly emphasize the importance of recent changes in court personnel. Two of the three most recent additions to the court, Judges Linn and Dyk, are among the most procedural in methodological approach, are highly likely to write "strong" expressions of methodological form, and rank among the most consistent of all judges in the dataset. ${ }^{190}$ Indeed, this pattern seems to be a generalized trend at the Federal Circuit, as Table 8 indicates.

${ }^{190}$ Note also that Judge Prost, whose small sample size necessitated her exclusion from some interjudge analyses, appears to be heading in this same direction. 
Table 8: The Changing Federal Circuit

\begin{tabular}{|l|c|c|c|c|}
\hline \multicolumn{1}{|c|}{ Judge } & $\begin{array}{c}\text { Joined } \\
\text { Court }\end{array}$ & $\begin{array}{c}\text { Procedural } \\
\text { (rank) }\end{array}$ & $\begin{array}{c}\text { Consistency } \\
\text { (rank) }\end{array}$ & Status \\
\hline Prost & 2001 & 4 & N/A & active \\
\hline Dyk & 2000 & 1 & 1 & active \\
\hline Linn & 2000 & 3 & 3 & active \\
\hline Gajarsa & 1997 & 8 & 7 & active \\
\hline Bryson & 1994 & 14 & 5 & active \\
\hline Schall & 1992 & 11 & 8 & active \\
\hline Rader & 1990 & 5 & 6 & active \\
\hline Clevenger & 1990 & 2 & 2 & active \\
\hline Lourie & 1990 & 13 & 11 & active \\
\hline Plager & 1989 & 10 & 12 & inactive \\
\hline Michel & 1988 & 6 & 4 & active \\
\hline Mayer & 1987 & 7 & 14 & active \\
\hline Archer & 1985 & 9 & 13 & inactive \\
\hline Newman & 1984 & 15 & 9 & active \\
\hline Friedman & 1978 & 16 & $\mathrm{~N} / \mathrm{A}$ & inactive \\
\hline Rich & 1956 & 12 & 10 & N/A \\
\hline
\end{tabular}

Table 8 orders judges in the dataset by the reverse chronology in which they joined the court (i.e., most recent appointments at the top). The junior judges appear to be generally more procedural and more consistent than their more senior colleagues. ${ }^{191}$ An important implication of Table 8 is that one might expect the trends identified in Part III.B, such as the increasing use of a procedural methodological approach, to continue-and perhaps even amplify-into the

191 Indeed, a Gamma test of association, which indicates the direction and strength of relationships between ordinal variables (such as those in Table 7) reveals a statistically significant negative correlation between Joined Court and both the Procedural (rank) and Consistency (rank) columns:

For Procedural (rank), $\gamma=-0.362, \mathrm{p} \leq 0.05$.

For Consistency (rank), $\gamma=-0.425, \mathrm{p} \leq 0.01$. 
future. ${ }^{192}$ In a significant way, we are watching the gradual emergence of the "new" Federal Circuit, a development that is already having profound effects on the court's jurisprudence.

In our view, whether the Federal Circuit is succeeding is a question that remains open. Little in our results would lead one to conclude that the court has been an unqualified success in bringing additional consistency, uniformity, and predictability to the patent law. Many findings, however, are unquestionably encouraging, suggesting that the court's effort to meet its mandate is both well underway and moving in the right direction.

\section{B. Policy Recommendations}

The findings outlined above, we believe, suggest several policy changes-both minor and major-that are likely to be beneficial to the achievement of the Federal Circuit's overall objectives. We discuss each of these briefly below.

\section{The Importance of Panel Composition Information}

As a general matter, the Federal Circuit does not reveal the identity of the judges assigned to a particular case until oral argument. Given our findings that the composition of panels affects the methodological approach to claim construction, and thus the appellate results in many cases, this policy has important effects, both positive and negative. ${ }^{193}$ On the negative side, keeping the panel membership a secret until oral argument dramatically decreases the chances of settlement while an appeal is pending; by the time that parties know of the identity of the panel, all costs of the appeal (writing briefs, filing fees, argument preparation, etc.) have been expended, removing perhaps the primary impetus for settlement. In contrast, a rule that allowed parties to know panel membership months in advance would increase both the time and the cost-incentives to settle the appeal. We believe the data in this Article offers important analytic tools for predicting claim construction analyses at the Federal Circuit; such information is likely to reduce the divergence between parties' expectations and thus

192 The rate and consistency of these trends will (of course) depend greatly upon future patterns of retirement and appointment to the Federal Circuit. The data in Table 7 suggest that those judges that are generally more holistic and less consistent are closest to retirement. There is the possibility that they could be replaced by judges with similar profiles, but this would run counter to recent history.

${ }^{193}$ Supra Part III.D. 
yield more settlements. ${ }^{194}$ More settlements means lower social costs and frees the Federal Circuit to spend additional time on the more difficult (less predictable) cases. A policy change by the court to release panel composition as soon as possible would be a simple, costfree way for the court to increase the settlement rate.

On the other hand, there are (perhaps counterintuitive) jurisprudential benefits to the Federal Circuit's current panel secrecy policy. One important finding of this study is that while several members of the Federal Circuit have relatively predictable effects on outcomes when empanelled, about half of the court does not. ${ }^{195}$ This in turn means that some panels will be more predictable than others-for example, those with a majority of "swing" judges or a combination of all three types. ${ }^{196}$ Given this understanding, one can predict that settlement rates when panel composition is known will be unequally distributed, with less settlement of panels that are relatively less predictable. ${ }^{197}$ This, then, has the potential of affecting the jurisprudence, with a larger proportion of opinions being decided by panels (and written by judges) that are less predictable. This, obviously, could have long-term negative effects on the overall performance of the court.

On balance, our view is that the jurisprudential concerns outweigh the social costs of less settlement, arguing at least weakly in favor of the current panel secrecy rule. ${ }^{198}$ Litigation is unquestionably expensive, but for the Federal Circuit to best achieve its mandates of clarity, consistency, and coherence, the loss of cost-reducing settlement opportunities by obscuring panel composition seems to us to be a cost that must be borne.

${ }^{194}$ Cf. George L. Priest \& Benjamin Klein, The Selection of Disputes for Litigation, $13 \mathrm{~J}$. LEGAL STUD. 1, 15-16 \& fig.6 (1984) (depicting how expectations can affect the likelihood of settlement).

${ }^{195}$ Supra Table 5.

${ }^{196}$ Supra Table 6 and Figure 8.

${ }^{197}$ See Priest \& Klein, supra note 194, at 15-16 (demonstrating the relationship between settlement rates and predictability).

${ }^{198}$ One common defense of the panel secrecy rule is that it limits parties' ability to tailor arguments to the perceived preferences of individual judges/panels. This is certainly true, though whether this is of substantial benefit is less clear; savvy advocates at the Federal Circuit will (especially in the wake of this study) present both procedural and holistic arguments in briefs and tailor their oral arguments more specifically. 


\section{Standardize (the Procedural) Methodological Approach}

One of the major findings of this study-that there exists a distinct (and enduring) split in the methodological approach to claim construction at the Federal Circuit-suggests that the court could make great strides in better meeting its mandate for uniformity and predictability by standardizing one of the two methodologies identified. ${ }^{199}$ Indeed, as we noted in Part III.B.2, the current methodological split on the Federal Circuit seems to be significantly related to reversals of district court claim construction analyses.

Of the two methodological approaches identified in this study, the procedural approach appears to be a far better choice, given the court's objectives. In particular, our results find a relatively strong and statistically significant relationship between a holistic methodological approach and variability (inconsistency), thereby implying that the holistic approach is inherently more difficult for judges to apply in a consistent and predictable manner. ${ }^{200}$ Further, while a complete articulation of the advantages of the procedural approach are beyond the scope of this Article, there are additional reasons to favor the procedural approach as well-especially the beneficial ex ante incentive effects, which can be expected to encourage patent claiming strategies that are both more clear and more direct, such as an increased use of carefully defined terms. As one of us has argued elsewhere, the ex ante effects of patent law jurisprudence are highly important to the overall operation of the patent administration system. ${ }^{201}$

\section{Taking Methodology Seriously}

Even absent agreement among Federal Circuit judges concerning the appropriate methodological approach to claim construction, our findings suggest that methodology must be taken seriously, for it is an element of the court's mission to manage the patent law towards greater uniformity and predictability.

Although there is some acknowledgement in the jurisprudence that different approaches do exist, the court does not appear to have meaningfully grappled with the implications of competing

199 An obvious mechanism for such standardization is en banc treatment of the appropriate methodological approach to claim construction.

${ }^{200}$ See infra Appendix A for details of this relationship.

201 See Wagner, supra note 80, at 167 (arguing for a shift from ex post to ex ante analysis in patent law jurisprudence). 
methodological schemes. Such concerns may be submerged beneath a desire to, for example, reach essentially the "right" result with a minimum of conflict-either within panels or between current and prior opinions. We note that the rate of alternative opinions was only $5.1 \%$. Given the approximately two-thirds/one-third methodological split in the jurisprudence and the wide variance between the judges' individual approaches, ${ }^{202}$ one would certainly expect more conflicts to be observed within the cases themselves. ${ }^{203}$ One possible explanation is that the judges on the Federal Circuit are simply unaware of the importance of methodological approach and/or take at face value the various jurisprudential efforts to "play down" distinctions in approach. Yet the results here would suggest that an avoidance-of-differences strategy, if it exists, has been unsuccessful at meaningfully avoiding doctrinal instability. Indeed, such plans radically diminish the precedential and predictive value of the court's opinions-that is, the use of the court's jurisprudence as a decision-making tool. Efforts by the court to "paper over" or "smooth out" the distinctions between the two methodological approaches described here are likely to only increase the overall variance of the claim construction results and thereby further set back the court's efforts to comply with its mandate. In our view, the court should select from among these methodological approaches (or develop a different one), and seek to apply it consistently.

\section{Evangelism and Enforcement: The Role of Individual Judges}

The findings here reveal, unsurprisingly, that individual judges play a significant role in the development of the Federal Circuit's jurisprudence of claim construction. Indeed, as discussed above, the observed trends appear to be closely related to the impact of a small number (two) of judges on the court in recent years. ${ }^{204}$ One recommendation that flows from these observations is that evangelism and enforcement activities by individual Federal Circuit judges should be encouraged and embraced, whether such activities take the form of dissenting opinions, internal discussions, or simply clearer statements

202 Supra Tables 4-5.

203 There could, of course, be a great deal of conflict among members of the court on this issue that is never seen from the outside.

204 See supra Part III.B.2 (discussing the impact of Judges Linn and Dyk). 
in the jurisprudence concerning methodology. ${ }^{205}$ As noted in Part III.C, our data indicates only modest (visible) efforts on the Federal Circuit in this regard-at least in this jurisprudential area. But we are hopeful that this could change; such leadership efforts on the part of individual judges will not only benefit the court's claim construction precedents, but establish a normative construct that is likely to improve the court's performance with respect to its overall mandate.

\section{Seeking External Assistance: The Role of the Supreme Court}

The serious methodological split we identify in the Federal Circuit's jurisprudence of claim construction raises the possibility, particularly in the absence of meaningful activities by the Federal Circuit to resolve the issue internally, of intervention by the Supreme Court. ${ }^{206}$ Our own view is that the present situation, especially in light of the observed trends, does not indicate an inability of the Federal Circuit to deal with this question. Nonetheless, recourse to the Supreme Court is a well-understood avenue for resolving otherwise intractable jurisprudential confusion. ${ }^{207}$

${ }^{205}$ As Justice Scalia's efforts with respect to statutory interpretation have illustrated, judges often act as enforcers of precedent and evangelists for particular approaches. See, e.g., Catherine T. Struve, The Paradox of Delegation: Interpreting the Federal Rules of Civil Procedure, 150 U. PA. L. REV. 1099, 1161-62 (2002) (noting that Justice Scalia will often "write[] separately-in cases where he agrees with the result reached by the Court-to disassociate himself from the Court's use of legislative history"); see also William N. Eskridge, Jr., The New Textualism, 37 UCLA L. REV. 621, 658 (1990) (noting that the Supreme Court has made an effort to downplay the role of legislative history in its decisions).

${ }^{206}$ The Supreme Court's recent history of intervention in Federal Circuit doctrine shows an increased willingness to get involved when internal disputes appear deep. For example, see Festo Corp. v. Shoketsu Kinzoku Kogyo Kabushiki, Co., 535 U.S. 722, 74042 (2002); Warner-Jenkinson Co. v. Hilton Davis Chemical Co., 520 U.S. 17, $40-41$ (1997); Markman II, 517 U.S. 370 (1996).

${ }^{207}$ The history surrounding the Supreme Court's Chevron decision, Chevron U.S.A. Inc. v. Natural Resources Defense Council, 467 U.S. 837 (1984), which was similarly characterized by distinct doctrinal splits and implications for institutional arrangements and design, is one example. See Cass R. Sunstein, Law and Administration After Chevron, 90 Colum. L. REV. 2071, 2079 (1990) (describing the tension between administrative agencies and the judiciary before Cheoron). For additional discussion of the impact of Chevron on the courts' approach to reviewing agency decision making, see Antonin Scalia, Judicial Deference to Administrative Interpretations of Law, 1989 DUKE L.J. 511, 517; Patricia M. Wald, Judicial Review in Midpassage: The Uneasy Partnership Between Courts and Agencies Plays On, 32 Tulsa L.J. 221, 241 (1996); Philip J. Weiser, Federal Common Law, Cooperative Federalism, and the Enforcement of the Telecom Act, 76 N.Y.U. L. REV. 1692, 171720 (2001). 


\section{CONCLUSION}

As an appellate body jurisdictionally demarcated by subject matter rather than geography, the United States Court of Appeals for the Federal Circuit occupies a unique role in the federal judiciary. This controversial institutional design has had profound effects on the jurisprudential development of the legal regimes within its ambit-especially patent law, which the Federal Circuit has come to thoroughly dominate during its two decades of existence.

In our view, whether the Federal Circuit is succeeding is a question which remains open. Little in the results above would lead one to conclude that the court has been an unqualified success in bringing additional consistency, uniformity, and predictability to patent law. But at the same time, many findings are unquestionably encouraging, suggesting that the court's effort to meet its mandate is both well underway and moving in the right direction. The picture of the Federal Circuit that emerges, we submit, is of a court in broad transition. Driven in part by new appointments and an effort to respond to its special mandate, a new Federal Circuit is emerging-one that appears to be more rules-driven and more consistent than before. It is too early to be sure, but the findings here, perhaps bolstered by the procedural and jurisprudential reforms we derive from the results, suggest that the Federal Circuit's unique position in the judiciary may yet be vindicated. 


\section{ApPendix A: The Relationship BetWeEn Methodology AND (IN)CONSISTENCY}

The following chart plots the methodological approach and variability of each judge in the dataset using authorship data.

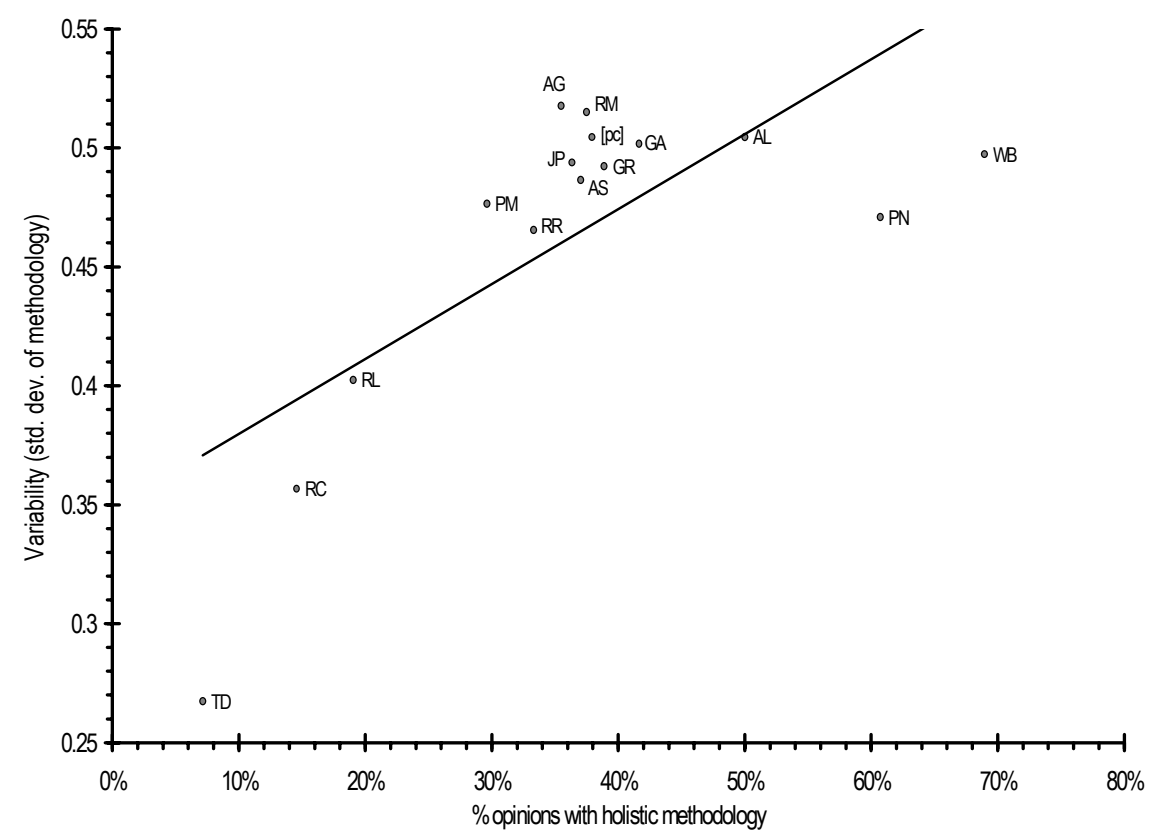

For the trendline, $R^{2}=.523, p \leq .005$, indicating a somewhat strong, statistically significant relationship. 